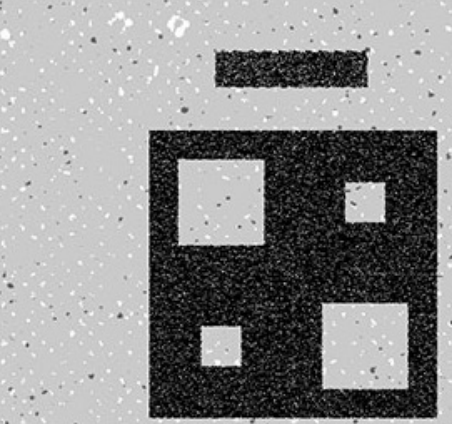

III
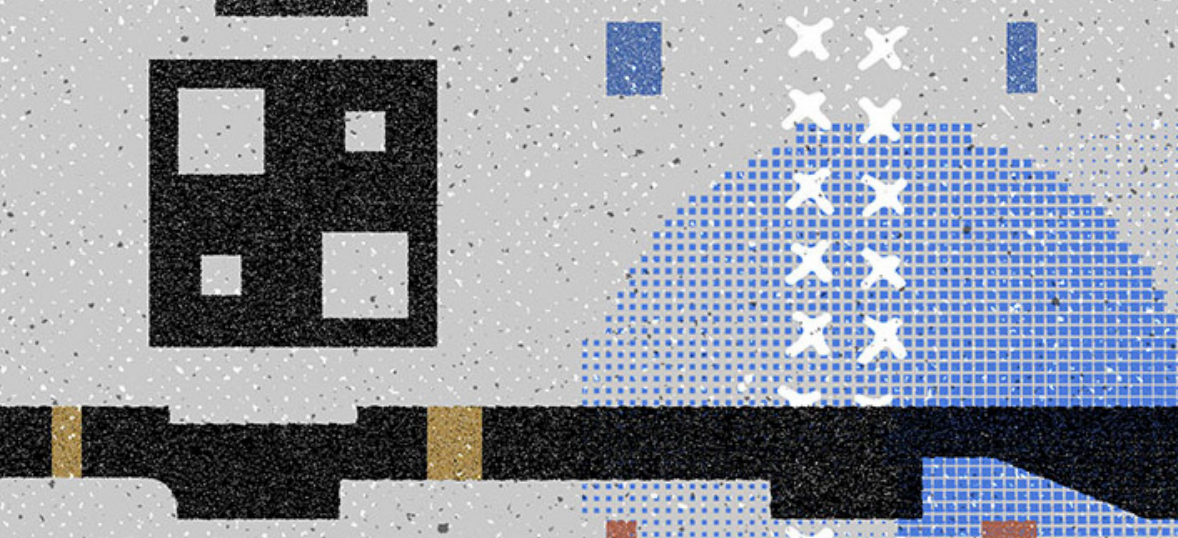

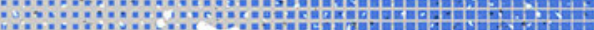
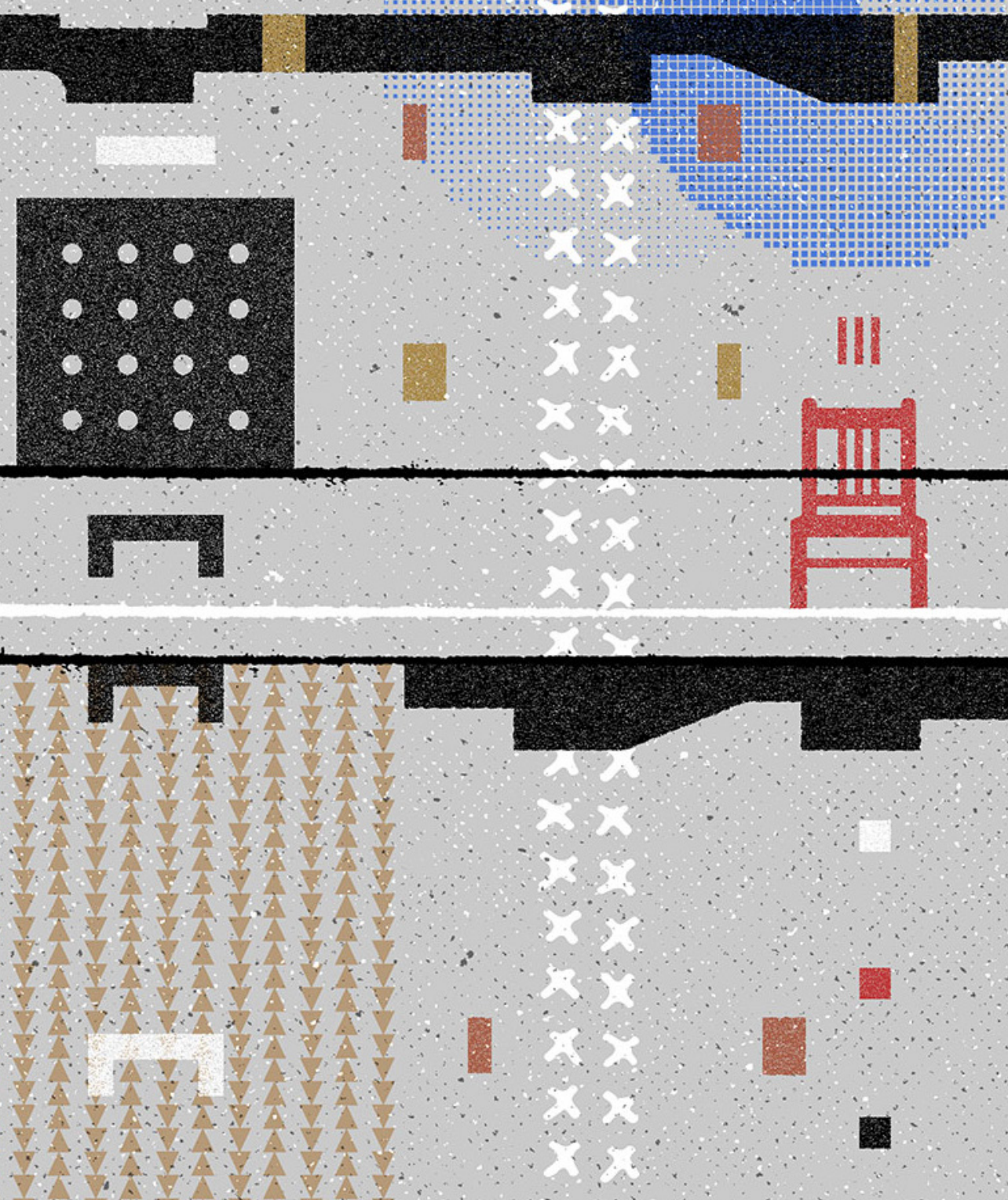


\title{
Estado e Capital Internacional no Processo de Industrialização Pesada no Brasil: uma Releitura do II Plano Nacional de Desenvolvimento (1975 - 1979)
}

\author{
State and International Capital in the \\ Brazilian Heavy Industrialization Process: \\ An interpretation of \\ II National Development Plan (1975-1979)
}

Acson Gusmão Franca*

\section{Resumo}

O presente artigo objetiva discutir o II Plano Nacional de Desenvolvimento (1975-1979), enquanto estratégia de desenvolvimento que propunha uma diversificação produtiva numa fase em que o ciclo econômico doméstico dava sinais de esgotamento. Para tanto, na primeira parte do mesmo será realizada uma releitura do documento oficial que lançou o II PND, identificando suas metas e diretrizes, bem como as fissuras existentes na estrutura montada pelo Estado. Em seguida, compreenderemos como o capital internacional dinamizou a execução das metas prioritárias do plano, através das joint ventures, de forma a submeter a empresa estatal aos seus desígnios. Por último, serão apresentados os limites criados capital internacional no decorrer desse processo, os quais resultaram no fracasso do II PND. Os resultados desse estudo nos revelam que, embora o plano tenha realizado parte de suas metas, o mesmo manteve o "desenvolvimento" da economia brasileira controlado pelos interesses do capital internacional.

Palavras-chave: Estado; Capital Internacional; Industrialização; II PND; Crise.

\begin{abstract}
This article aims to discuss the II National Development Plan (1975-1979), as a development strategy that proposed a productive diversification in a phase in which the domestic economic cycle showed signs of exhaustion. Therefore, in the first part of it will be held a rereading of the official document that launched the II PND, identifying its goals and guidelines, as well as the cracks in the structure assembled by the state. Next, we will understand how international capital has streamlined the execution of the plan's priority goals, through joint ventures, in order to subject the state-owned company to its goals. Finally, the limits created by international capital during this process will be presented, which resulted in the failure of the II PND. The results of this study show us that although the plan has achieved part of its goals, it has kept the "development" of the Brazilian economy controlled by the interests of international capital.
\end{abstract}

Keywords: State; International Capital; Industrializa tion; II PND; Crisis.

\footnotetext{
* Professor na Universidade Federal dos Vales do Jequitinhonha e Mucuri (UFVJM). Graduado em Ciências Econômicas pela UFVJM e Mestre em Desenvolvimento Econômico pelo Instituto de Economia da Universidade Estadual de Campinas. https://orcid.org/0000-0002-4303-2251.E-mail: acson_franca@yahoo.com.br
} 


\section{INTRODUÇÃO}

No início da década de 1970, o longo ciclo de crescimento e prosperidade capitalista iniciado em meados da década de 1950, fruto do processo de reconstrução econômica dos países da Europa e Ásia e dos acordos de Bretton Woods, entrou em colapso. Isto é, após um período de forte acumulação de capital, liderado pela grande corporação norte-americana durante os chamados "anos dourados" o capitalismo vivenciou uma crise estrutural, cujos impactos não se restringiram apenas à esfera produtiva, abrangendo também a totalidade da vida social (MESZAROS, 2009).

Mandel (1990) a definiu como uma crise clássica de superprodução da economia capitalista, fruto da lógica da expansão do próprio sistema, que ao fazer avançar o processo de acumulação, criou as condições para a redução na taxa de lucros e, consequentemente, para o acirramento das contradições inerentes ao mesmo. Desde o início desta longa crise "o capital tudo fez no sentido de romper com as amarras das relaçốes sociais, leis e regulamentaçôes” que enalteciam a falsa ilusão de que era possível prendê-lo e civilizá-lo. E teve êxito nessa empreitada ${ }^{1}$ (CHESNAIS, 1995, p. 2).

De fato, a ruptura com os acordos de Bretton Woods em 1971 e 1973 determinou o fim do padrão dólar-ouro, acabando com a convertibilidade direta do dólar em ouro, o que gerou uma forte desvalorização de $8 \%$ no dólar, desencadeando aquilo que muitos autores definiram como crise da hegemonia norte-americana ${ }^{2}$ (EICHENGREEN, 2000). Em virtude dessa desvalorização da moeda americana em relação às moedas dos demais países do centro, os Estados Unidos impuseram o padrão dólar-flexível, cuja dinâmica de funcionamento causou mudanças na política externa estadunidense, resultando no aumento da liquidez internacional.

Outro fator que contribuiu nesse processo foi a ocorrência do primeiro choque do petróleo em 1973, que permitiu a um grupo de países exportadores de petróleo acumular uma grande quantidade de reservas sob a forma de certificados de depósito em bancos internacionais - os petrodólares (FURTADO, 1992). A reciclagem desses petrodólares serviu, de antemão, para os países periféricos como meio de financiamento dos seus programas de desenvolvimento, porém, consequentemente fazia aumentar o endividamento dos mesmos, que ao recorrer a esse crédito externo colaborava para a exacerbação do capitalismo financeiro mundial.

Foi nessa fase que se iniciou no centro do sistema um processo de reestruturação produtiva das empresas multinacionais, o qual incidiu diretamente sobre o comportamento dessas empresas, fazendo emergir um novo padrão de acumulação capitalista caracterizado pela financeirização, precarização do trabalho, dentre outras mazelas oriundas do neoliberalismo que negam o 
planejamento econômico enquanto instrumento de desenvolvimento nacional (CAMPOS, 2016). Nessa conjuntura, o Estado refirmou o seu papel de agente multifacético, que atúa a serviço da mundialização do capital, visto que passou a criar formas de atrair empresas multinacionais, fazendo das mesmas as principais beneficiárias de sua intervenção.

Para a economia brasileira isso representou a queda dos pilares que haviam sustentado o seu crescimento econômico em meados dos anos 1950, cedendo espaço aos novos mecanismos de crédito oriundos do Euromercado $^{3}$, responsáveis pela desestruturação do sistema produtivo nacional através da armadilha do endividamento externo. Isto é, em meio aos limites encontrados pelo padrão mundial de acumulação durante o esgotamento do ciclo de acumulação industrial do Plano de Metas, a constituição do Euromercado abriu para o capital internacional novas perspectivas de valorização na economia brasileira, uma vez que seu espaço de mobilidade foi ampliado "por meio da conexão direta das filiais estrangeiras à grande oferta de liquidez dos mercados offshore” (CAMPOS \& RODRIGUES, 2014, p. 390).

Após a efetivação do Golpe de 1964, o capital internacional pôde aliar suas estratégias de acumulação interna às novas facilidades de financiamento externo oferecidas pelo Euromercado (CAMPOS, 2009), de forma a definir os limites do desenvolvimento nacional perante a transnacionalização (FURTADO, 1992). As condiçóes institucionais criadas pelo Estado durante o PAEG conectaram o sistema financeiro internacional ao espaço econômico brasileiro já controlado pelas filiais estrangeiras, que passaram a realizar contrataçóes líquidas de empréstimos e financiamentos externos para expandir suas atividades

Nesse processo, em que a internacionalização de capitais transitava da sua fase produtiva para a financeira, Ernesto Geisel assumiu a Presidência do Brasil; enseguida, encaminhou ao Congresso Nacional no dia 10 de setembro de 1974 um documento contendo o II PND. Em Dezembro do mesmo ano o documento foi aprovado e publicado no Diário Oficial por meio da Lei no $6.151^{4}$, que determinou as diretrizes e prioridades a serem seguidas no quinquênio 1975- 1979.

Nesse sentido, o presente artigo se propóe a compreender o II PND na sua totalidade, partindo da sua concepção teórica, passando pelo seu processo de execução, até a sua crise. Para tanto, o mesmo é composto por três partes distintas, mas complementares. $\mathrm{Na}$ primeira, a partir releitura do documento oficial que lançou o II PND, serão identificadas suas metas, diretrizes e fissuras existentes na estrutura montada pelo Estado. $\mathrm{Na}$ segunda, compreenderemos como o capital internacional dinamizou a execução das metas prioritárias do plano, submetendo a empresa estatal aos seus interesses. 
Por último, serão apresentados os limites criados por esse capital no decorrer desse processo, os quais, além resultaram no fracasso desse plano, direcionou a economia brasileira para uma situação de crise e estagnação.

\section{O II PLANO NACIONAL DE DESENVOLVIMENTO (II PND)}

O II PND foi apresentado pelo então Presidente do Brasil como uma estratégia de desenvolvimento proposta pelo Estado brasileiro, que objetivava sustentar o crescimento econômico alcançado pela economia brasileira no período do "Milagre Econômico (1969-1973)" , através de uma mudança nas prioridades da industrialização brasileira. Esperava-se que a economia continuasse a crescer, porém, "puxada fundamentalmente pelo setor de meios de produção, ou seja, pela indústria de equipamentos e pela indústria de insumos de base" (LESSA, 1977, p. 52).

Apesar da crise internacional e do excesso de endividamento externo brasileiro proveniente da década anterior, o Presidente da República garantia que a realização do II PND traria as condições necessárias para que a economia brasileira superasse tanto a desaceleração cíclica da produção, quanto os estrangulamentos estruturais existentes nos setores básicos da economia, tornando-se uma potência emergente, como pode ser conferido nesse discurso por ele proferido:

Não é menos certo, que drásticas mudanças ocorridas no cenário mundial como a grave crise de energia (...) a instabilidade no sistema monetário internacional, a inflação que se generaliza pelo mundo todo a taxas alarmantes (...) determinarão sérias repercussões no panorama nacional sobretudo num ano de intensa atividade política como o ano de 1974, e que significativos eventos ocorreram na vida nacional. Isso não significa abandonar o Primeiro Plano Nacional de Desenvolvimento, ainda vigente para este ano, mas que, de fato, tratar-se-á de completá-lo, prolongá-lo e de complementá-lo através do Segundo Plano em elaboração, dentro de diretrizes básicas análogas, porém, adequadas à presente situação e à sua possível evolução nos próximos anos (GEISEL, 1974, p. 8).

Para tanto, o Estado brasileiro montou uma estrutura de planejamento, composta por organismos internos e alguns instrumentos de execução, que, segundo Ernesto Geisel, se encarregaria de definir novas prioridades da política econômica para o próximo quinquênio. Em seguida, essa mesma estrutura colocaria em prática o referido plano, seguindo as diretrizes predefinidas pelo governo (VELOSO, 1978). No entanto, quando analisamos o seu modo de funcionamento, notamos que, na prática, a referida estrutura se ajustou à nova onda de capitais que ingressaram aqui nessa fase, como forma de aliar o crescimento econômico com o endividamento externo. Nesse processo,as 
empresas privadas brasileiras e, sobretudo, as estatais assumiram novamente a função de sócias locais das empresas multinacionais, sendo utilizadas na captação recursos financeiros e gerenciais, máquinas e equipamentos externos, cujo pagamento por isso recaía sobre o Estado brasileiro (CAMPOS, 2009).

Essa obrigação que o Estado assumiu serviu para dirimir os riscos dos novos Investimentos Diretos Estrangeiros (IDE) ingressados aqui, e principalmente, para manter as burguesias brasileiras na sua posição privilegiada. Vejamos a seguir as partes que compunham essa estrutura, para entendermos como o seu modo de funcionamento submetia desenvolvimento da economia ao imperialismo.

Até aquele momento as mudanças corridas no padrão de financiamento, fruto das reformas institucionais realizadas pelo Estado autoritário, serviram para ampliar as condiçóes que permitiam maior mobilidade do capital internacional e, por sua vez, aprofundar nossa dependência externa (CAMPOS \& RODRIGUES, 2014). Assim, o padrão de financiamento adotado permaneceu constituído por recursos oferecidos pelo BNDE, outros captados através de transferências dos fundos do Programa de Integração Social (PIS) e do Programa de Formação do Patrimônio do Servido Público (PASEP) da Caixa Econômica Federal, mas, principalmente de empréstimos externos oriundos do Euromercado (CAMPOS, 2009).

Além disto, nesse intervalo de tempo a equipe econômica de Ernesto Geisel anunciou medidas que tinham o propósito de angariar outros recursos externos necessários para implementar os propostas do plano. Estas, por sua vez, também repercutiam diretamente no aumento da dívida externa brasileira, principalmente do setor público, como a Circular no $230^{6}$ por meio da qual o Banco Central (BACEN) assumiria o endividamento privado (RODRIGUES, 2017).
A partir de Agosto de 1974 passou a ser permitido que os recursos não utiliza- dos nas operaçốes financeiras de repasse fossem aplicados na forma de depósitos em moeda estrangeira junto ao BACEN, como alternativa à compra de Letras do Tesouro Nacional (LTN). Sobre tais depósitos o BACEN assumiria os juros devidos ao credor externo e, também, o ônus do imposto de renda quando de responsabilidade do depositante (Circular n. 230) (CRUZ, 1984, p. 41).

Essa conexão do sistema financeiro nacional com o circuito financeiro internacional estabelecida desde meados da década de 1960, através da Lei 4.131 (1962) 63 e 64 de 1967, foi reafirmada na década de 1970 pelas novas regulamentaçốes criadas pelo Estado brasileiro ${ }^{8}$. (RODRIGUES, 2017). Por um lado, a criação desses novos canais de entrada para o capital internacional permitiu 
o surgimento de novas fontes de financiamento; por outro, possibilitava o crescimento da dívida externa brasileira.

Além destes, um dos principais instrumentos de ação do II PND criados pelo Estado para gerir a política industrial da época, de forma a incentivar a participação do capital internacional na realização das metas prioritárias da indústria brasileira, teve participação direta nesse aumento do endividamento externo brasileiro. O Conselho de Desenvolvimento Industrial (CDI), composto por representantes do BNDE, BACEN e alguns ministérios, era o órgão estatal interno responsável por estimular as importações de máquinas e equipamentos, através da concessão de subsídios e isenções fiscais a empresas que apresentassem projetos industriais para essas atividades e, sobretudo, por avaliá-los (BONELLI \& MALAN, 1976). Para aprovar tais projetos, o conselho definia alguns critérios de seletividade a serem observados, tais como: volume do investimento, tamanho do empreendimento, etc., que beneficiavam às empresas multinacionais detentoras da maior parte dos projetos de grande porte, com longo prazo de maturação.

De fato, a proposta inicial de Geisel para realizar as metas do II PND era a de manter o tripé que vinha desde o Plano de Metas, no qual a empresa estatal seria o personagem mais estratégico da economia brasileira, se instalando novamente em setores que o capital privado não tinha interesse de atuar naquela fase, mas que eram considerados essenciais para o desenvolvimento capitalista brasileiro, tais como: energia, transportes, comunicação, saúde, educação. Na medida em que essas empresas empurrassem para frente os projetos desses setores, "elas gerariam uma demanda de bens de capital que permitiriam à empresa privada nacional e estrangeira, investir, ampliando a produção interna de bens de capital” (LESSA, 1977, p.54). Enquanto isso, o desenvolvimento das áreas mais lucrativas, como a indústria de transformação ficaria inteiramente a cargo da iniciativa privada, como pode ser conferido abaixo:

1) Os setores de Infraestrutura Econômica, normalmente através de empresas governamentais, em Energia, Transportes e Comunicaçôes, operando articuladamente com os Estados e Municípios. Nessas áreas de concessão de serviços públicos, o setor privado [atuaria] complementarmente, na forma que for definida. Todavia, as indústrias produtoras de equipamentos materiais para tais setores, pertencentes à Indústria de Transformação, não [eram] áreas de responsabilidade do Governo, e sim da iniciativa privada; 2) As áreas de Desenvolvimento Social, frequentemente em ação conjugada com a iniciativa privada: Educação, Saúde, Previdência Social (a Habitação [era] caso especial, pois a ação executiva [caberia], em geral, ao setor privado). Constituem campo de atuação próprios da área privada setores diretamente produtivos: Indústria de Transformação, Indústria de Construção, Agricultura e Pecuária, Comércio, Seguros, Sistema 
Financeiro (ressalvada a função pioneira e de estímulo atribuída aos bancos oficiais). Nesses setores, não apenas o Governo [confiava] seu desenvolvimento à iniciativa privada, como [procurava] provê-la das condiçôes para um desenvolvimento satisfatório, através de incentivos fiscais, financeiros, políticas de preços e outros estímulos (II PND, 1974, 48-49).

Dos novos programas e projetos previstos pelo II PND que seriam "liderados" pela empresa estatal, destacamos aqueles existentes no setor de insumos básicos, cuja execução ficaria a cargo dos esquemas de participação acionária e de financiamento criados pelo BNDE e por outras entidades governamentais para garantir a associação das estatais brasileiras com empresas privadas, como estabelecia o documento oficial ${ }^{9}$. Neste grupo, incluímos o Programa Petroquímico, o Plano Siderúrgico Nacional e os Planos Especiais para Fertilizantes Papel e Celulose, que abrangiam os projetos direcionados a exploração do minério de ferro - Carajás/ Pará; de bauxita - Trombetas/Pará; cobre - Caraíbas/Bahia; fosfatados - Patos/Minas Gerais; Carvão e Pirita - Santa Catarina e Rio Grande do Sul; Sal - Nordeste, siderurgia - Itaqui/ Maranhão, Tubarão/Espírito Santo - as usinas minerais Açominas e Mendes Junior. Além destes, havia a proposta de criar o II Polo Petroquímico da Bahia, o complexo cloroquímico - Maceió/Alagoas; complexo de exploração de potássio - Sergipe; exploração de nitrogenados - Norte Fluminense, fertilizantes - Minas Gerais, dentre outros projetos ligados a exploração do cimento, papel e celulose implantados no Nordeste, Sul da Bahia e Norte Capixaba (LESSA, 1977 \& VELOSO, 1978).

Em todos esses projetos, a atuação das empresas estatais brasileiras Insumos Básicos S.A (FIBASE), Petrobrás Química S.A (PETROQUISA), Siderúrgica Brasileira (SIDERBRAS) - e de suas subsidiárias servia para propagar a crença existente por parte do Estado de que, ao aumentar a sua participação na economia brasileira nesse e nos demais setores de infraestrutura, ele potencializaria o capital privado nacional, e, em seguida, teria condiçóes futuras de submeter as empresas multinacionais aos desígnios nacionais (NONNEMBERG, 2003) ${ }^{10}$. Todavia, essa centralidade assumida, tanto pelo Estado, quanto pela empresa estatal na orientação da política econômica nacional, estava relacionada ao papel que, na prática, ambos desempenhariam novamente no suporte à acumulação do setor privado.

Em outras palavras, caberia ao Estado direcionar os investimentos realizados pelo setor privado nacional e internacional, seja pela demanda originada nas empresas estatais, principalmente por bens de capital, seja por meio dos incentivos concedidos a alguns setores industriais prioritários aos interesses privados (ABRANCHES, 1977). Era, portanto, uma forma seletiva de impulsionar o processo de industrialização articulando os investimentos 
públicos e privados. "E não apenas por esses dois fatores, mas, por meio de ações destinadas a atrair, sobretudo, diretamente sócios estrangeiros para setores predeterminados" (NONNEMBERG, 2003, p. 9).

\section{A EXECUÇÃO DO II PND}

Para alcançar o êxito esperado pelas propostas do II PND, o Estado brasileiro precisava garantir que as suas relaçóes estabelecidas com o capital privado nacional e internacional no período concernente ao Plano de Metas fossem reafirmadas. Isso era uma condição prévia para a atração de investimentos estrangeiros não apenas para os setores de infraestrutura (transporte, energia, comunicação e etc.) e de insumos básicos, mas, sobretudo, para o setor de bens de capital, considerado o principal "gargalo" interno a ser resolvido pela política desenvolvimentista de Geisel.

Daí advém a necessidade de compreendermos a atuação da empresa estatal, enquanto instrumento interno de valorização desses capitais privados durante a execução do plano (RODRIGUES, 2017), assumindo funçóes cada vez mais específicas no modelo brasileiro de capitalismo industrial defendido pelo II PND.

\section{A Empresa Estatal}

A proposta do II PND de ampliar as funçôes do Estado na produção de serviços e insumos básicos, considerados setores de baixa rentabilidade, estava ligada à necessidade de as empresas estatais prosseguirem gerando economias externas, que beneficiassem às empresas privadas, principalmente as multinacionais, nas diferentes etapas do processo de execução das metas setoriais do plano (RODRIGUES, 2017) Em 1974, por exemplo, "foram criadas as três irmãs - FIBASE, EMBRAMEC e IBRASA - como companhias de investimento para assumirem participações acionárias minoritárias em projetos inscritos nas prioridades da Estratégia” (LESSA, 1998, p. 224).

De acordo com Trebat (1980), a principal função assumida por essas empresas nessa fase era a criar novamente as condiçóes que permitiam ao setor privado ampliar as suas operaçóes na economia brasileira. E isso poderia ocorrer de formas distintas. A primeira e mais comum era resultante da demanda necessária por máquinas e equipamentos produzidos no setor de bens de capital, que a realização dos projetos existentes nos setores liderados pela empresa estatal criava (BAER, 1986). Essa demanda, por sua vez, estimulava a produção e a lucratividade desse setor, cujo desenvolvimento não estava sob o controle do Estado e sim da iniciativa privada. 
Outra forma encontrada pelo Estado para continuar garantindo a apropriação privada foi influindo no padrão de desenvolvimento capitalista, dando sustentabilidade institucional à associação dessas empresas estatais com o capital internacional e as privadas nacionais na formação das chamadas de joint ventures (CAMPOS, 2009). De acordo com Zoninson e Teixeira (1983), as facilidades encontradas por elas no que se refere ao acesso à produção local de insumos e aos sistemas de comercialização e distribuição, aliados às leis, práticas administrativas e subsídios criados pelas pelo Estado brasileiro traziam inúmeros benefícios para as mesmas. Isto é, faziam com que esse processo de criação de novos setores produtivos e modernização das atividades já existentes permanecessem controlados pelo capital internacional.

Também se faz necessário ressaltarmos a funcionalidade dessas empresas estatais, enquanto instrumento da política de endividamento externo do governo. Dada a baixa capacidade de autofinanciamento das estatais e dos limites à sua participação no mercado de açôes e no mercado interno de crédito, estas empresas tinham a missão de captar um volume crescente de empréstimos em moeda estrangeira no mercado financeiro internacional, para serem aplicados internamente, segundo os interesses das pelas empresas privadas. (CAVALCANTI, 1998).

Vejamos como a articulação dessas empresas com os interesses do grande capital internacional e do capital nacional - tripé do desenvolvimento -, possibilitou a realização de alguns projetos do II PND, conforme as prioridades do novo Investimento Direto Estrangeiro (IDE).

\section{Os Setores de Infraestrutura: Energia e Transporte}

O binômio formado pelos setores de transporte e energia assumia uma posição crucial nessa nova estratégia de internacionalização, visto que seria inviável atrair investimentos externos para os demais setores abrangidos pelo II PND, sem que ocorressem alterações substanciais nestas áreas de infraestruturas. A construção de novas plantas industriais nas regiốes mais estratégicas do país, bem como a integração das mesmas com as regióes mais periféricas, dependia da realização das metas contidas na tabela 1 (LESSA, 1977).

De acordo com a tabela, as medidas adotadas pelo Estado brasileiro para o setor energético se concentraram em fomentar a exploração de novas fontes de energia, pela intensificação da pesquisa e da prospecção de petróleo. Essa opção nos revela como Ernesto Geisel fez da primeira crise do petróleo (1973) uma justificativa para a proclamação de outros projetos direcionados não apenas a esse setor, mas também ao setor de transportes e industrial (LESSA, 1977). 
Tabela 1 - Metas previstas para os setores de Energia e Transportes (1974 - 1979)

\begin{tabular}{l|l|c|c|c}
\hline Setores & & 1974 & $\begin{array}{c}\text { Previsto para } \\
1979\end{array}$ & $\begin{array}{c}\text { Aumento } \\
\text { previsto para } \\
\text { o período (\%) }\end{array}$ \\
\hline \multirow{2}{*}{ Energia } & Potência Instalada (milhões de kW) & 17,6 & 28 & 59 \\
\cline { 2 - 5 } & Consumo (bilhões de kW/h) & 61 & 107 & 75 \\
\cline { 2 - 5 } & $\begin{array}{l}\text { Petróleo - Capacidade de refino } \\
\text { (mil barris/dia) }\end{array}$ & 1020 & 1650 & 62 \\
\hline \multirow{2}{*}{ Transporte } & $\begin{array}{l}\text { Rede Rodoviária Federal Pavimentada } \\
\text { (mil km) }\end{array}$ & 41,2 & 63 & 37 \\
\cline { 2 - 5 } & $\begin{array}{l}\text { Rede Rodoviária Federal não } \\
\text { Pavimentada (mil km) }\end{array}$ & 33,5 & 45,8 & 124 \\
\cline { 2 - 5 } & $\begin{array}{l}\text { Total da Frota de Navegação de Longo } \\
\text { Curso (mil tpb) }\end{array}$ & 4205 & 9438 & 58 \\
\cline { 2 - 5 } & Total da Frota de Cabotagem (mil tpb) & 612 & 967 & 75 \\
\cline { 2 - 5 } & Petroleiros & 1297 & 2280 & 167 \\
\hline
\end{tabular}

Fonte: II PND (1974)

Para o alcance das metas propostas na política de energia do II PND, a Petrobrás rompeu com o monopólio estatal definido pela Lei 2.004/54, criando uma subsidiária para negociar e executar os contratos de risco de exploração no Brasil e em países estrangeiros, a Petrobrás Internacional Braspetro ${ }^{11}$. Esses contratos estabeleciam vantagens para os sócios estrangeiros desde a oferta de serviços através de associação, até a formação de jointventures, tal como ocorreu no setor.

Pelos contratos, a Petrobrás ou Braspetro atua em parceria com vários dos "trustes", com outros consórcios estrangeiros, ou com companhias de petróleo nacionais, e receberá no máximo apenas parte do petróleo produzido por suas descobertas; realmente, no Iraque, a Braspetro/Intebrás tem direito apenas a "comprar", a "preços favoráveis", parte do petróleo que venha a descobrir (enquanto pagará à Iraq National Oil Company um "bônus" durante dez anos) (SMITH, 1976, p.199).

"A verdade é que o contrato de risco abriu precedente à instalação dos principais oligopólios internacionais no setor petrolífero, permitindo um avanço do capital internacional sobre a economia brasileira" (CAMPOS, 2009 , p. 151). No final de 1976, a Petrobrás e a Braspetro já havia assinado uma série desses contratos com trustes internacionais oriundos de países, como: Colômbia, Iraque, Egito, Irã, Madagascar, Argélia e Líbia, os quais concentraram os seus esforços na perfuração e produção das plataformas continentais nas áreas de Campos (Rio de Janeiro), Uberana (Rio Grande do Norte), Sergipe e Alagoas ${ }^{12}$. 
Devido a essa internacionalização na área petrolífera, o índice de produção de petróleo brasileiro subiu para 10,5\% nos primeiros meses do ano de 1976. Todavia, essa quantidade era insuficiente para atender a demanda nacional por essa matéria-prima, sendo necessário importar de fontes estrangeiras pagando um alto preço por isso ${ }^{13}$. Isso teve um respaldo direto no preço interno do barril, o qual se elevou de US\$13,60 em 1978 para US\$30,03 em 1979. Por isso quando ocorreu o segundo choque do petróleo (1979) o Brasil já importava 87\% do que consumia deste recurso (BAER, 1993).

No que diz respeito ao aumento da capacidade interna de produção de energia elétrica, destacamos aqui a construção da Usina Hidroelétrica Itaipu, como o resultado de uma aliança estratégica entre os Estados paraguaio e português e algumas empresas privadas nacionais e multinacionais na realização de um projeto apoiado no aumento do endividamento externo brasileiro, via importaçôes e empréstimos externos. Orçado inicialmente em U\$ 44 bilhões de dólares, as dimensões dessa usina abrangiam a Foz do Iguaçu, no Brasil, e Ciudad do Leste, no sul do Paraguai, até Guaíra e Salto del Guairá, no Norte deste país. Para realização desse empreendimento, no início de 1970 foi assinado o Convênio de Cooperação entre as Centrais Elétricas Brasileiras S.A (ELETROBRAS) - Chesf, Furnas, Eletrosul e Eletronorte - e a Administración Nacional de Eletricidad (ANDE) do Paraguai. (SILVA, 2006, p. 98).

Em consonância a isto, em 26 de abril de 1973, Brasil e Paraguai assinaram o Tratado de Itaipu ${ }^{14}$, que estabeleceu as normas e diretrizes a serem seguidas por esses países para o aproveitamento hidrelétrico dos recursos hídricos do Rio Paraná. No referido tratado foi definido a criação da Itaipu Binacional, uma empresa surgida da vontade desses dois Estados (Brasil e Paraguai), incumbida de coordenar e supervisionar a construção da hidrelétrica, que se protegeu "sob a lei de segurança nacional, com legislação específica e foi diretamente subordinada ao governo federal" (ANDERSEN, 2009, p. 8). Isto é, tratava-se de um organismo internacional, sob a forma de uma empresa estatal com um direito de propriedade e exercido em comum pelos dois Estados soberanos (MIRANDA, 2008).

As obras foram iniciadas pela binacional ainda em 1975, utilizando de recursos provenientes da abertura de uma linha de crédito da Eletrobrás no valor de 3,5 bilhões de dólares, aliados a atuação de quatro consórcios. Os consórcios Unicon (brasileiro) e Conempa (paraguaio) formados por grandes grupos privados existentes nesses países ficaram responsáveis pela parte da construção civil, enquanto as obras de montagem e eletromecânica foram executadas pelos consórcios Itamon (brasileiro) e Consórcio de Ingeniería Electromecánica S.A (paraguaio). Esses consórcios ${ }^{15}$ eram compostos 
por estatais e outras empresas privadas brasileiras e internacionais que se instalaram aqui para concluir as obras dentro do prazo.

No final da década de 1970, com o agravamento da situação econômica do Brasil, a Eletrobrás teve que recorrer a empréstimos externos de curto prazo de bancos estrangeiros, tais como: Deutsche Bank, Morgan International e Citibank, tendo que pagar altas taxas de juros pelos mesmos ${ }^{16}$ (CAUBET, 1989). Essa obrigação, somada as despesas diretas do empreendimento com obras civis, importação de equipamentos, engenharia, supervisão e etc., fizeram com que os custos do Projeto Itaipu Binacional crescessem rapidamente ao logo desse período, como mostra a tabela 2 .

Tabela 2 - Evolução dos Custos do Projeto Itaipu Binacional (em 10 $0^{3}$ US\$)

\begin{tabular}{l|c|c|c}
\hline Ano & $\begin{array}{c}\text { Custos diretos } \\
\text { (em 10 }\end{array}$ & $\begin{array}{c}\text { Juros durante a } \\
\text { construção } \\
\text { (em 10 } 10^{3} \text { US\$) }\end{array}$ & $\begin{array}{c}\text { Custos totais } \\
\text { (em 10 } 0^{3} \text { US\$) }\end{array}$ \\
\hline 1974 & 2.869 .266 & 1.373 .794 & 4.243 .060 \\
\hline 1976 & 3.872 .350 & 1.979 .300 & 5.851 .650 \\
\hline 1978 & 5.934 .000 & 2.788 .400 & 8.722 .400 \\
\hline 1980 & 8.010 .350 & 4.692 .150 & 12.702 .500 \\
\hline 1982 & 9.297 .720 & 5.995 .180 & 15.292 .900 \\
\hline
\end{tabular}

Fonte: Dados obtidos no site institucional da Itaipu Binacional já citado

Do total desses custos gerados pela construção da Itaipu Binacional apresentados na tabela acima, o pagamento desses juros da dívida externa contraída externamente pela Eletrobrás incidiu sobre o Estado brasileiro, que também "foi obrigado a comprar a energia de Itaipu, mesmo quando não havia demanda, com preço estipulado pelo Tratado, superior ao praticado pelo mercado" (CAUBET, 1989, p.261). Ademais, o Estado brasileiro teve que pagar ao Estado paraguaio royalties por ter cedido a outra parte de energia necessária para a realização dos projetos de Itaipu.

Esses royalties foram pagos através de dólares dos Estados Unidos da América, referente ao seu padrão de peso e título em ouro, na época, sendo previsto também que este valor poderá ser substituído no caso em que a mencionada moeda deixar de ter referida sua paridade oficial em relação ao ouro (MIRANDA, 2008, p.19).

$\mathrm{Na}$ área de energia nuclear, em novembro de 1975 foi assinado o Acordo Nuclear Brasil - República Federal da Alemanha (RFA), o qual previa a instalação de oito centrais nucleares, com reatores de $1300 \mathrm{MW}$ de potência. Para isso, o referido acordo determinava a necessidade da transferência 
integral da tecnologia atômica da empresa alemã Kraftwerk Union (KWU), de forma a dotar o Brasil de uma autonomia em todo o ciclo de tecnologia nuclear, incluindo o enriquecimento do urânio e o reprocessamento do combustível (BRANDÃO, 2008).

Após tomar conhecimento disso, o governo norte-americano, temendo que esse acordo atrapalhasse os seus interesses comerciais e estratégicos, convenceu o governo alemão a inserir rígidos controles na transferência da tecnologia nuclear para o Brasil e a intervir internamente na realização dos projetos direcionados a construção de usinas termonucleares em alguns estados brasileiros (WROBEL, 1986). Com isso, a produção de energia nuclear no Brasil permaneceu controlada pela tecnologia alemã e refém do "consentimento" norte-americano.

No que tange aos transportes, a realização dos projetos de ampliação da malha rodoviária brasileira (Transamazônica, Cuiabá-Santarém, BelémBrasília, etc) prosseguiram encontrando problemas para a liquidação das faturas do DNER e dos Departamentos de Estradas e Rodagens (DERs) estadual (LESSA, 1998). No que refere à ampliação da malha ferroviária, Geisel criou o Programa de Desenvolvimento Ferroviário, definindo o investimento de mais de U\$ $\$ 3,5$ bilhões para a conclusão do mesmo. Entretanto, em razão do elevado custo das obras e da baixa produtividade do setor que já entrava em decadência, a Rede Ferroviária Federal S.A (RFFSA) não conseguiu atrair novos investimentos privados para o setor (BARAT, 1978). Esses impasses impediram que o desenvolvimento do sistema ferroviário nacional ocorresse, de fato, mantendo o setor rodoviário como principal beneficiário da intervenção estatal.

Para o programa naval inscrito no II PND foi elaborado em 1976 o Plano de Construção Naval, que previa investimento na ordem de 3,3 bilhões de dólares, contratando 5.300.000 TPB, e concluir 1.300.00 TPB já contratados no plano anterior, também para atender aos mercados interno e externo. "O objetivo era fazer do Brasil uma potência mundial na construção naval, ao lado do Japão e da Coreia do Sul, ampliando as exportações de manufaturados” (FILHO, 2014, p. 4). Para tal, o estado brasileiro permitiu que os grupos estrangeiros Ishikawajima Brasil Estaleiros S.A (ISHIBRAS) e Verolme, já instalados aqui, continuassem a executar a maior parte dos projetos do setor, mas, devido ao esgotamento dos padróes de financiamento, esses empreendimentos começaram a operar com capacidade ociosa, enquanto outros foram cancelados. 


\section{O Setor Industrial}

\section{As indústrias de base}

No setor industrial, a estratégia de diversificação produtiva proposta por Geisel se organizava em torno de dois objetivos contraditórios. Por um lado, buscava viabilizar o desenvolvimento da indústria brasileira, por meio da ativa participação do setor privado internacional na realização dos projetos, por outro, assegurar à empresa nacional papel importante na estrutura industrial que se desejava consolidar (II PND, 1974). Para tanto, o Estado brasileiro priorizou a implantação de projetos orientados a ampliar a produção da indústria de insumos básicos, como apresenta a tabela 3 .

Tabela 3 - Metas Propostas para a Indústria de Insumos Básicos (1974 -1979)

\begin{tabular}{|c|c|c|c|c|}
\hline Setores & Ramo & 1974 & $\begin{array}{l}\text { Previsto } \\
\text { para } 1979\end{array}$ & $\begin{array}{l}\text { Aumento previsto } \\
\text { para o período (\%) }\end{array}$ \\
\hline \multirow{6}{*}{$\begin{array}{l}\text { Siderurgia e } \\
\text { Metalúrgica } \\
\text { (Capacidade Instalada, } \\
\text { em mil t) }\end{array}$} & Aço em lingotes & 8600 & 22300 & 159 \\
\hline & $\begin{array}{l}\text { Laminados Planos e Perfis } \\
\text { Pesados }\end{array}$ & 4100 & 13100 & 220 \\
\hline & $\begin{array}{l}\text { Laminados Não-Planos e Aços } \\
\text { Especiais }\end{array}$ & 4600 & 8300 & 80 \\
\hline & Alumínio & 120 & 190 & 58 \\
\hline & Cobre & 10 & 60 & 500 \\
\hline & Zinco & 33 & 58 & 76 \\
\hline \multirow{6}{*}{$\begin{array}{l}\text { Química (Capacidade } \\
\text { Instalada, em mil t) }\end{array}$} & Ácido Sulfúrico & 986 & 3388 & 244 \\
\hline & $\begin{array}{l}\text { Soda Caústica e Barrilha (em } \\
\text { Na2O) }\end{array}$ & 273 & 700 & 156 \\
\hline & Cloro & 212 & 593 & 179 \\
\hline & Amônia & 268 & 577 & 115 \\
\hline & Fertilizantes (NPK) & 585 & 1199 & 105 \\
\hline & Detergentes (em DDB) & 27 & 75 & 178 \\
\hline \multirow{3}{*}{$\begin{array}{l}\text { Bens Intermediários } \\
\text { Não-Metálicos } \\
\text { (Capacidade Instalada, } \\
\text { em mil t) }\end{array}$} & Cimento & 17130 & 26190 & 53 \\
\hline & Celulose & 1547 & 2860 & 85 \\
\hline & Papel & 2267 & 2900 & 28 \\
\hline \multirow[t]{2}{*}{$\begin{array}{l}\text { Mineração (Capacidade } \\
\text { Instalada, em mil t) }\end{array}$} & $\begin{array}{l}\text { Produção de Minério de Ferro } \\
\text { (milhões t) }\end{array}$ & 60 & 138 & 130 \\
\hline & $\begin{array}{l}\text { Exportações de Minério de } \\
\text { Ferro (milhões t) }\end{array}$ & 44 & 98 & 123 \\
\hline
\end{tabular}

Fonte: II PND (1974)

Essa grande quantidade de metas conferidas ao setor era explicada, sobretudo, pela articulação que as indústrias siderúrgicas, metalúrgicas, químicas, mineração, etc., mantinham com as empresas multinacionais produtoras de bens de capital por meio da demanda, (BAER, 1986). O fato é que a execução 
dos empreendimentos existentes nas primeiras indústrias dependia do uso de máquinas e equipamentos pertencentes às últimas, as quais detinham o controle dessas tecnologias. Para essas empresas, era mais lucrativo empregar uma tecnologia produzida no centro do que em um país subdesenvolvido, como o Brasil, pois "o custo adicional do uso de tecnologia num mercado novo é desprezível, se comparado ao custo de desenvolver inicialmente essa tecnologia” (EVANS, 1980, p. 46).

$\mathrm{Na}$ indústria de insumos básicos, os maiores empreendimentos realizados foram produto da aliança societária das empresas estatais brasileiras SIDERBRAS, FIBASE e PETROQUISA etc - e de suas subsidiárias, com empresas privadas nacionais e multinacionais japonesas e europeias. $\mathrm{Na}$ indústria siderúrgica, por exemplo, em julho de 1974 o Conselho de Desenvolvimento Econômico (CDE) aprovou as diretrizes relativas à implantação do Plano Siderúrgico Nacional (PSN) orientado a ampliar as três grandes usinas nacionais - Companhia Siderúrgica Nacional (CSN) Cosipa e Usiminas - e construir duas grandes usinas: Itaqui, no Maranhão, e Tubarão, no Espírito Santo (Lessa, 1998). Essas, por sua vez, foram construídas partir de 1976 pela Cia. Nipo-Brasileira de Pelotização, uma joint venture formada pela associação da Companhia Vale do Rio Doce (CVRD), uma subsidiária da SIDERBRAS, com multinacionais japonesas produtoras de aço, tais como: Nippon Steel Co. e Kawasaki.

A participação acionária dessas empresas na execução desses projetos do setor siderúrgico brasileiro integrava um novo ciclo de investimentos diretos japoneses no Brasil, o qual não ocorreu apenas por meio do investimento de capital de risco (TORRES FILHO, 1990). O país passou também a fornecer capital de investimento e tecnologia siderúrgica, a qual foi incorporada internamente pelos técnicos brasileiros.

Para um país, como o Brasil, que dispóe de excelentes e volumosos depósitos de minérios de ferro, que aproveita os cargueiros que transportam o minério exportado para importar carvão, cuja poupança não chega às necessidades de financiar um ambicioso plano siderúrgico e que ainda precisa importar tecnologia, a solução de multinacionais no modelo da usina de Tubarão é altamente indicada. Por seu turno em termos mais modestos, o Brasil está também estudando uma multinacional siderúrgica com o Paraguai e talvez uma com a Bolívia (CANTANHEDE, 1976, p.113).

O modelo de gestão aplicado pelos técnicos japoneses desde a montagem desses dois empreendimentos não se restringiu apenas aos projetos do PSN, sendo posteriormente incorporado pelos técnicos brasileiros em outros projetos do setor metalúrgico, químico, elétrico, material pesado etc. (TORRES FILHO, 1990). Assim, o desenvolvimento setorial brasileiro continuava a 
reproduzir internamente o chamado know-how japonês, bem como suas técnicas e conhecimento.

$\mathrm{Na}$ indústria metalúrgica, a expansão da oferta dos insumos requeria a construção de novas usinas e reservas. Para aumentar a produção de alumínio, por exemplo, o II PND depositou suas esperanças no complexo Alunorte - Albrás, cuja construção dependia das negociações entre as multinacionais japonesas - Light Metal Association, Mitsui Aluminium, Showa e a Nippon Light Metal - com a CVRD (LESSA, 1998). Entretanto, por conta da diversificação de interesses existentes nos dois lados das negociaçóes para a formação da joint venture, Alumínio Brasileiro Ltda, a meta foi reduzida à metade e a conclusão desse projeto ficou prevista para 1985, extrapolando o prazo estabelecido pelo Presidente (EVANS, 1980).

Em relação à produção de cobre, a construção do complexo metalúrgico da Caraíba Metais/Bahia, considerado o empreendimento mais significativo da época, estava inicialmente nas mãos do Grupo Pignatari, mas foi transferido posteriormente para a carteira da recém-criada FIBASE/BNDE ${ }^{17}$. Sob o comando da FIBASE, a realização desse projeto custou aproximadamente U\$\$ 600 milhóes, incluindo os recursos aplicados na construção de outro complexo metalúrgico, o de Camaquã no Rio Grande do Sul. Uma parcela expressiva desta quantia foi adquirida sob a forma de empréstimos externos, com taxas de juros flutuantes, acompanhando a variação da taxa de juros negociada no London Interbank Offered Rate (LIBOR) (BNDES, 1986).

$\mathrm{Na}$ indústria química, as joint ventures criadas, tinham a PETROQUISA e a PETROBRÁS associadas aos capitais norte-americanos, japoneses e europeus (CAMPOS, 2009). Em potássicos, o Grupo Lume Financiliar, formado por um grupo de sócios estrangeiros do setor imobiliário ganhou a disputa com a Companhia de Pesquisa Recursos Mineral (CPRM) pela direito a pesquisa e lavra das substancias minerais brasileiras, passando a ser dono de $50 \%$ das reservas de potássio de Carmóplis, uma das regióes que mais o produziam no Brasil. Em 1976, o grupo admitiu ampliar a participação da PETROQUISA nas decisôes referentes ao setor; contudo se recusou a vender as suas ações, avaliadas em U\$ $\$ 1,3$ bilhão, continuando a investir no setor na década seguinte (LESSA, 1998).

$\mathrm{Na}$ área de nitrogenados, a construção e ampliação do Polo Petroquímico de Camaçari e de outros projetos em implantação em Araucária (Paraná) e Laranjeiras (Sergipe) seria, num primeiro momento, uma tarefa da PETROBRÁS (OLIVEIRA, 2004). Mas, por conta das dificuldades relacionadas à obtenção de recursos externos e da falta de experiência dessa estatal com o uso das tecnologias, ela optou por convidar petroquímicas japonesas (Mitsubishi, Sumitomo, Nisho - Iwai) que aceitaram entrar como sócio 
minoritário nesse projeto, se associando aos capitais privados internos de empresas, como a Camargo Corrêa ${ }^{18}$. Em seguida, "alguns grandes grupos licenciadores europeus e norte-americanos (Shell, Dupont, dentre outros) entenderam que o modelo a três lhes daria a possibilidade de entrarem no país e ingressaram no setor" (SCHUTTE, 2004, p. 107).

$\mathrm{Na}$ indústria de fertilizantes fosfatados, a exploração das grandes reservas minerais descobertos pela CPRM esteve sob o controle da própria CPRM, das subsidiárias da CVRD e de outros grupos privados, os quais detinham $40 \%$ do capital investido, como o grupo Argentino Bunge $\Xi^{\circ}$ Borne. No que se refere à indústria farmacêutica, o Estado brasileiro não possuía até o início da década de 1970 nenhum controle significativo sobre os recursos naturais e as tecnologias necessárias para aumentar a produção dos medicamentos, tendo que importá-los de outros países para atender as necessidades da população ${ }^{19}$. Diante disso, permitiu que grupos privados internacionais, tais como: F. Hoffman - La Roche Co. (Suíça), Cia. Ind. Produtora de Antibióticos (Portugal) penetrassem na indústria brasileira com apoio da FIBASE, formando as duas joint ventures: Alagoas Matérias-Primas e Farmacêuticos e Cia. Brasileira de Antibióticos, responsáveis pela maior parte da produção da indústria no período e na década posterior. Essas empresas patrocinaram a construção de laboratórios e outros centros direcionados a realizar novas pesquisas no Brasil.

$\mathrm{Na}$ indústria de bens intermediários, especificamente no que se refere a produção de papel e celulose, em dezembro de 1974 o Conselho de Desenvolvimento Econômico estabeleceu as metas do Programa Nacional de Papel e Celulose, cuja realização caberia a Japan - Brazil Pulp Resources Development, uma joint venture formada pela associação da CVRD com o capital japonês e norte-americano (EVANS, 1980). Todavia, devido à iminência de cortes do BNDE, aliados à alta dos preços dos equipamentos importados a serem utilizados, os projetos desse setor foram rapidamente cancelados e só voltaram a serem executados na década de 1980 .

Para a indústria de mineração existia um projeto de exploração do minério de ferro da Serra dos Carajás, o qual exigia uma vultosa quantidade de investimentos externos para entrar em execução (CANTANHEDE, 1976). Estes, de antemão, seriam obtidos com a grande empresa norte-americana, U.S. Steel, que, para se associar a CVRD, se dispôs a aceitar uma posição minoritária nesse empreendimento, exigindo em troca disso o poder de veto nas negociaçôes do conselho diretor (EVANS, 1980). Contudo, a CVRD, temendo perder sua "autonomia" no fórum de negociações, recusou a participação da empresa e optou por contrair novos empréstimos junto ao Banco Mundial. 
O resultado obtido pela indústria de insumos básicos nesse período em que as joint ventures promoveram a execução de grande parte de suas metas, seguindo as prioridades do novo IDE, pode ser conferido na tabela abaixo:

Com base na tabela acima, notamos que, ao mudarem sua estratégia de acumulação e direcionarem os seus investimentos para a indústria brasileira de insumos básicos, formando as joint ventures, as empresas multinacionais possibilitaram esse aumento na produção da mesma e, consequentemente, das exportações brasileiras no setor, no período 1970 - 1980. Essa ampliação da capacidade produtiva dessa indústria, porém, se deu, sobretudo, à custa de uma rápida elevação na pauta de importaçóes brasileiras, o que gerava consequentemente pressóes indesejáveis no balanço de pagamentos e na taxa de inflação da economia brasileira (BONELLI \& MALAN, 1976).

\section{A indústria de bens de capital}

A consolidação da indústria de bens de capital constituía um "componente crítico para a mudança do padrão de industrialização brasileiro" (LESSA, 1998, p. 121). Isto é, construir na economia brasileira uma indústria doméstica de máquinas e equipamentos mais complexa, diversificada e de maior nível tecnológico, era considerada a principal lacuna que a política industrial do II PND se propunha a fechar (BONELLI \& MALAN, 1976). Para tanto, o II PND estabeleceu algumas metas direcionadas ao setor, ambas apresentadas na tabela 5 .

Tabela 4 - Coeficientes da Indústria de insumos básicos 1970 - 1980 (dados em Cr\$ milhões de 1970)

\begin{tabular}{c|c|c|c}
\hline Ano & Produto Industrial & Exportações & Importações \\
\hline 1970 & 95.513 & 2.459 & 11.869 \\
\hline 1971 & 106.87 & 2.790 & 15.631 \\
\hline 1972 & 121.77 & 3.887 & 19.109 \\
\hline 1973 & 141.93 & 4.023 & 22.812 \\
\hline 1974 & 153.01 & 4.046 & 32.104 \\
\hline 1975 & 158.83 & 4.484 & 28.822 \\
\hline 1976 & 179.37 & 4.658 & 25.594 \\
\hline 1977 & 184.62 & 5.768 & 22.730 \\
\hline 1978 & 197.80 & 7.404 & 24.048 \\
\hline 1979 & 210.98 & 8.340 & 26.213 \\
\hline 1980 & 227.03 & 10.206 & 28.377 \\
\hline
\end{tabular}

Fonte : Bonelli e Malan (1976) apud Serra (1998). 
"De saída, o presente desafio esbarrava na incapacidade estatal de articular diversos interesses de blocos de capitais em torno dessas metas" (CAMPOS, 2009, p. 88). Em maio de 1974 foi constituída a Mecânica Brasileira S.A - EMBRAMEC, uma estatal criada para controlar a realização dos empreendimentos do setor, ampliando a capacidade das empresas privadas nacionais na contratação de financiamentos externos (LESSA, 1977). Porém, a sua atuação como um instrumento de capitalização específico para o setor de bens de capital se chocou nas relutâncias dos empresários proprietários dessas empresas do setor no que tange o acesso às tecnologias necessárias.

A solução encontrada pelo Estado para garantir à indústria de bens de capital um nível de investimentos capaz de atender as encomendas internas, sem romper com os prazos estabelecidos no cronograma do II PND foi agir de igual forma à indústria de insumos básicos. Ou seja, permitir que empresas multinacionais detentoras dessas tecnologias se instalassem no país de forma associada à EMBRAMEC e a essas empresas privadas, formando joint ventures, para atuarem na execução desses projetos. Ao recorrer ao know-how dessas empresas por meio do controle de transferência tecnológica e ao incentivo a construção das bases do $\mathrm{P} \& \mathrm{D}$ no setor, por meio da política de longo prazo ao fomento da ciência aplicada, estariam superadas as principais debilidades que impediam o desenvolvimento do setor (CAMPOS, 2009).
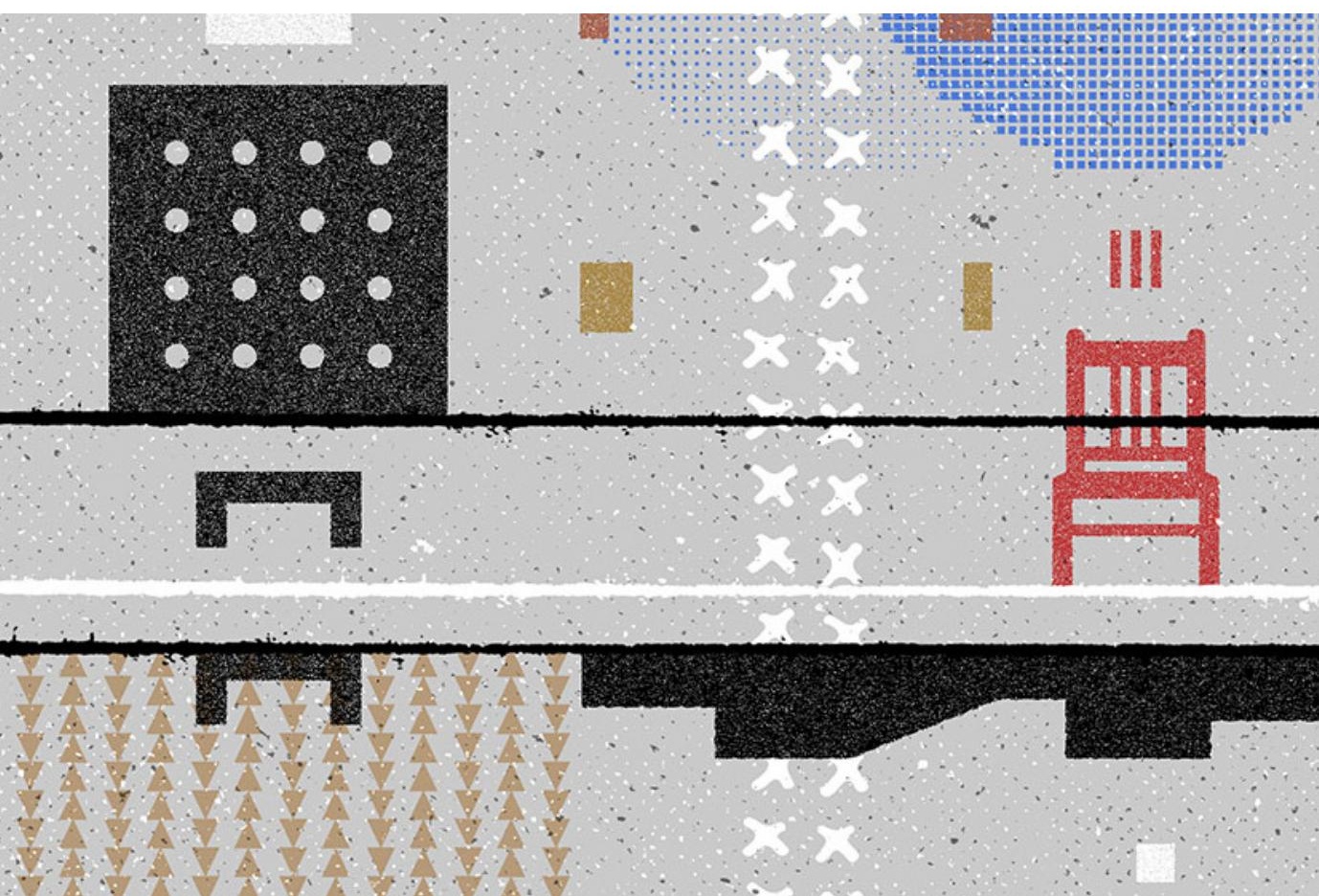
Nesse processo, a atuação do Instituto Nacional da Propriedade Industrial (INPI), criado no início da década de 1970 em substituição ao antigo Departamento da Propriedade Industrial (DPI), cumpriria um importante papel nessa política de transferência tecnológica, de modo as suas principais atribuições seriam as de "executar a legislação que regulava a propriedade industrial (marcas e patentes), impulsionar a transferência de tecnologia, além de fiscalizar tratados, acordos e convênios sobre propriedade Industrial” (CAMPOS, 2009, p. 164). Enquanto isso, o CDI se prestaria em incentivar as importaçóes de máquinas e equipamentos no Brasil de acordo com as constantes encomendas realizadas pelas empresas multinacionais (MARTINS, 1985). Assim, à medida que os projetos do setor fossem realizados, ocorreria uma piora no balanço de pagamentos brasileiro. Ou seja, "a substituição de importaçôes do setor de bens de capital só poderia ocorrer ao custo de maiores importaçóes, logo, de maior vulnerabilidade externa" (FISHLOW, 1986, p. 522).

Apesar do esforço do Estado no sentido de promover à formação de joints ventures com empresas estrangeiras, garantindo ao sócio nacional participação majoritária nos empreendimentos, a indústria de bens de capital não decolou, de fato. (ZONINSON \& TEIXEIRA, 1983). Ainda assim, durante o primeiro ano em que o II PND esteve em exercício, parte dos projetos do setor de bens de capital foi concluída, de modo que a produção corrente da indústria apresentou um crescimento superior a $10 \%$ a.a. A partir de 1976, a realidade da crise internacional ganhou contornos mais nítidos na política econômica brasileira, impactando diretamente no crescimento da produção doméstica. Em virtude disso, a execução dos projetos ainda existentes no setor de bens de capital passou a depender cada vez mais das importaçôes realizadas pelas empresas estatais, que, em meio a essas consequências, se comprometeu a adquirir de fornecedores externos não apenas máquinas e equipamentos, mas também créditos combinados (suplier's credits) para a compra de outros bens, gerando um descontentamento na indústria nacional (MANTEGA, 1979).

As poucas empresas privadas que tinham apostado no II PND e ampliado as suas capacidades de produção se viram frente ao acirramento da competição internacional e à redução das garantias de demanda assegurada pelas estatais, que tiveram grande parte de seus projetos cancelados (SERRA, 1998). Não demorou para que esse descontentamento dos empresários do setor contra a "ingratidão" do Estado ganhasse a opinião pública, como afirmou Moraes (2018, p.145, grifos do autor):

[...] O Estado passou a ser visto como o agente causador da crise, e o arbítrio com que comandava todas as esferas da economia foi apontado como o seu pro- 
blema maior. Passou a serem mais frequentes, a partir de então, manifestaçôes empresariais de oposição ao governo, no que viria a ser chamada "Campanha Antiestatização.

Esse embate entre o setor de bens de capital representado pela Associação Brasileira de Desenvolvimento da Indústria de Base (ABDIB) e o Estado se colocou como um dos determinantes do fracasso do II PND, pois a reação das lideranças dessa fração empresarial nacional no sentido de "reforçar o movimento de crítica à política econômica do II PND sob a forma de uma campanha contra a estatização, levou-o a um patamar de maior radicalidade”20 (MACARINI, 2011, p. 111). Isso fez com que esse setor entrasse em conflito com o próprio capital internacional.

Nessa ordem de conflitos que se estabeleceu entre o Estado e o setor de bens de capital, e entre este e os fornecedores externos, o caso da indústria aeronáutica brasileira se colocou de maneira distinta, devido a autonomia imposta pela estatal - Empresa Brasileira de Aeronáutica (EMBRAER) - nas negociações com empresas multinacionais, e posteriormente, no processo de execução dos projetos do setor (CAMPOS, 2009). Para a realização dos projetos propostos para o setor aeronáutico, a EMBRAER negociou com três empresas multinacionais (Cessna, Beech e Piper), mas acabou firmando um contrato com a última; a norte-americana Piper Aircraft Corporation, no qual estabelecia algumas exigências para que a referida empresa se adequasse às "regras do jogo", tais como: 1) condições mínimas para desenvolver suas próprias capacidades técnicas, administrativas, industriais e de marketing na produção de avióes pequenos, reservando o mercado interno somente para os aviôes produzidos no Brasil; 2) autoridade para fazer modificações que julgasse adequadas nos avióes fabricados (BARANSON, 1980). Com o tempo, esse esforço brasileiro de desenvolver sua indústria aeroespacial atingiu bons resultados.

No âmbito produtivo e tecnológico, o período estatal foi marcado pela construção de uma empresa do zero, sem experiência de produção em escala industrial, para uma empresa capaz de dominar técnicas avançadas de projeto, construção e montagem de avióes. Apesar dos limites dos tipos de aeronaves construídas, de muito menor complexidade do que as feitas pelas grandes companhias - Boeing, McDonnell Douglas, Lockheed Martin, British Aircraft Corporation ou Airbus -, a Embraer conseguiu atingir um patamar competitivo no seu nicho de avióes comerciais e alcançar aprendizado tecnológico nos projetos mais avançados de então, o AMX e o CBA-12321 (CARDOSO, 2018, p. 104).

Nas demais indústrias localizadas no setor de bens de capital, bem como naqueles que estavam sob o comando das empresas estatais, esse conflito com o capital internacional criou um ambiente de incertezas, que foi prejudicial 
aos investimentos privados e, consequentemente, à realização dos empreendimentos que dependiam deles. A participação do investimento privado no total de investimento realizado na economia brasileira, que era de $60 \%$ em 1974, diminuiu nos anos posteriores, vindo a recuperar, ainda que parcialmente, apenas em 1978, quando atingiu quase 55\% (REICHSTUL \& COUTINHO, 1983).

Desse modo, a manutenção do dinamismo da economia brasileira dependia da capacidade do Estado em sustentar blocos de investimentos concatenados no tempo. Porém, essa opção estava inviabilizada naquele momento, tanto do ponto de vista produtivo como financeiro (TAVARES \& ASSIS, 1985). Nesse cenário, muitos dos projetos prioritários dos setores de infraestrutura, metalurgia e siderurgia etc. não foram concluídos, outros foram abandonados, ocasionando a diminuição das encomendas ao setor de bens de capital, que passou a carregar uma capacidade produtiva excedente.

Diante dessa redução da demanda, a produção doméstica do setor de bens de capital caiu paulatinamente, exibindo um crescimento de apenas 3,4\% a.a. de 1977 a 1980, considerado o desempenho setorial mais fraco alcançado pelo setor (SERRA, 1998). Essas e outras contradições intrínsecas ao II PND puseram fim às premissas originais, que defendiam a existência de uma sincronia entre os investimentos realizados nos setores de bens de capital e insumos básicos capaz de sustentar o crescimento da economia brasileira através da demanda.

\section{OS LIMITES}

Desde a sua concepção teórica até a sua prática, o II PND tentou reproduzir no seu conjunto de metas setoriais a ser executado o espírito "desenvolvimentista" do Plano de Metas nos marcos de um novo padrão de acumulação capitalista apoiado no crescente endividamento externo (MACARINI, 2011). Por ser considerado o único meio de facilitar o ajustamento do balanço de pagamentos e de financiar o crescimento proposto para o período, a dependência do endividamento externo se tornou a base dessa estratégia de desenvolvimento que defendia a conflitante possibilidade de a economia brasileira adquirir uma maior autonomia relativa frente ao sistema mundial, sem romper com a situação de subordinação.

Nesse sentido, ao instituir os organismos internos (CDI, empresas estatais, INPI, etc.), bem como os demais instrumentos de execução, o Estado brasileiro optou por manter o processo de expansão e diversificação dos setores prioritários do II PND controlado pelo capital internacional, tanto via empréstimos externos e importaçôes, quanto da participação acionária 
de empresas multinacionais na formação de joint ventures, etc (NONNEMBERG, 2003). Essa escolha, ainda que se colocasse como melhor alternativa para superar os problemas conjunturais causados pela crise mundial, criava certos limites à crescente atuação do setor público na condução da política econômica, sendo estes de natureza financeira e tecnológica.

$\mathrm{Na}$ medida em que o objetivo era construir capacidade produtiva em larga escala no setor de bens intermediários, e crescer aceleradamente, teria de haver problema de balanço de pagamentos, bem como desequilíbrio interno. Continuavam necessárias as importaçôes de máquinas e equipamentos, embora crescentemente restringidas, enquanto o mercado doméstico absorvia exportáveis. O Estado estimulava a demanda, ao mesmo tempo em que implementava seus ambiciosos planos, defrontando-se com a dificuldade de financiá-los. (FISHLOW, 1986, p. 523).

O primeiro destes, referente à questão financeira, era resultado do destaque dado às empresas estatais pelo Plano, as quais tiveram que recorrer a empréstimos externos para prover os fundos necessários, em moeda local, a execução dos projetos prioritários aos interesses do capital internacional, fazendo aumentar o endividamento dessas empresas junto aos bancos privados internacionais (CAVALCANTI, 1998). A tabela 6 nos mostra como isso contribuiu para o aumento da dívida externa do setor público, por meio da Lei 4.131.

De acordo à tabela 6, entre os anos 1972 e 1973, quando ocorreu o primeiro momento de crescimento elevado do endividamento externo brasileiro, o setor privado detinha quase $70 \%$ de toda a dívida, visto que eram as empresas privadas as principais demandantes desses empréstimos. A partir de 1975, com a formação das joint ventures, as estatais assumiram a responsabilidade de recorrer a esses empréstimos para concluir os empreendimentos nos setores de infraestrutura e insumos básicos. Isso fez com que o endividamento do setor privado diminuísse de 49,6\% em 1975, para 23,2\% em 1979. Nos anos 1979-1980, período em que grande parte dos projetos do II PND havia sido abandonada e as estatais tiveram que absorver parte do endividamento privado, houve uma inversão nesse percentual de participação, de forma que o setor estatal passou a responder por mais de $75 \%$ de toda a dívida externa brasileira.

Ademais, é importante observarmos que os setores que mais receberam empréstimos externos durante o período de execução do II PND foram os de energia e siderurgia, de modo que parte deles foi direcionada as obras de Itaipu e ao PSN. Enquanto no setor de energia a sua participação aumentou de 3,6\% em 1972 para 25,1\% em 1980, no segundo ela passou de $0,2 \%$ em 1972 para $7,9 \%$ em $1980^{22}$. 


\begin{tabular}{|c|c|c|c|c|c|c|c|c|c|c|c|}
\hline$\delta^{\circ}$ & $\begin{array}{l}0 \\
80\end{array}$ & $\begin{array}{l}\text { ñ } \\
\stackrel{\nu}{0}\end{array}$ & $\stackrel{\mathcal{F}}{\sim}$ & $\hat{\sigma}$ & $\bar{m}$ & ก̃ & $\hat{\text { in }}$ & $\begin{array}{l}0 \\
\infty\end{array}$ & $\stackrel{+}{+}$ & 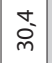 & 옴 \\
\hline $\begin{array}{l}\bar{\infty} \\
\stackrel{\sigma}{\sigma}\end{array}$ & 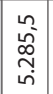 & 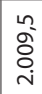 & $\frac{O}{i}$ & $\begin{array}{l}\text { ָे } \\
\text { กิ }\end{array}$ & ホั & 옴 & $\begin{array}{l}\text { ָे } \\
\text { ఫे }\end{array}$ & $\bar{\pi}$ & $\frac{m}{\dot{q}}$ & $\begin{array}{l}\Sigma \\
\bar{m} \\
\stackrel{N}{n}\end{array}$ & 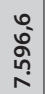 \\
\hline$\delta^{\circ}$ & $\begin{array}{l}0 \\
0 \\
0\end{array}$ & $\sqrt{\mathrm{N}}$ & $\stackrel{\Omega}{\curvearrowright}$ & กี & 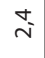 & $\stackrel{\infty}{\sim}$ & $\Xi$ & $\Sigma$ & $\stackrel{\circ}{m}$ & $\underset{\sim}{\stackrel{v}{\sim}}$ & 음 \\
\hline$\stackrel{\circ}{\circ}$ & $\begin{array}{l}0 \\
i \\
\infty \\
0 \\
\dot{m}\end{array}$ & స్ & $\begin{array}{c}N \\
\infty \\
\stackrel{\infty}{m}\end{array}$ & $\begin{array}{l}\text { ㅇ. } \\
\text { ஸे }\end{array}$ & $\begin{array}{l}\stackrel{\sigma}{m} \\
\stackrel{-}{\sigma}\end{array}$ & ০̀ & $\begin{array}{l}\hat{n} \\
\hat{n} \\
\hat{n}\end{array}$ & 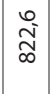 & in & $\begin{array}{c}\overline{ \pm} \\
\underset{I}{-}\end{array}$ & $\begin{array}{l}\bar{\Sigma} \\
\bar{\infty} \\
\dot{+}\end{array}$ \\
\hline${ }^{\circ}$ & $\begin{array}{l}\infty \\
0^{-} \\
\wedge\end{array}$ & $\begin{array}{l}\stackrel{n}{\infty} \\
\stackrel{\infty}{\infty}\end{array}$ & $\stackrel{0}{\circ}$ & $\stackrel{n}{\leftarrow}$ & 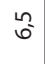 & $\stackrel{0}{m}$ & $\underset{\infty}{N}$ & స̃ & $\hat{N}$ & $\begin{array}{l}\tilde{N} \\
\tilde{N}\end{array}$ & ঃ \\
\hline 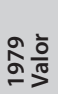 & $\begin{array}{l}\mathscr{\sigma} \\
\mathcal{Y} \\
0 \\
0 \\
0\end{array}$ & $\begin{array}{l}\bar{\alpha} \\
\text { s. } \\
\end{array}$ & $\frac{0}{n}$ & $\begin{array}{l}\stackrel{\sigma}{m} \\
\stackrel{m}{\sigma}\end{array}$ & $\begin{array}{l}0 \\
\circ \\
\text { in }\end{array}$ & Ò্ & $\begin{array}{l}0 \\
\vdots \\
i\end{array}$ & 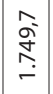 & 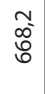 & $\begin{array}{l}\stackrel{+}{\Delta} \\
\stackrel{\Delta}{0} \\
\dot{N}\end{array}$ & $\begin{array}{l}m \\
0 \\
0 \\
0 \\
\infty \\
\infty\end{array}$ \\
\hline$\therefore$ & $\tilde{c}$ & $\begin{array}{l}\stackrel{n}{n} \\
\stackrel{n}{n}\end{array}$ & જે & $\cong$ & 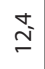 & $\stackrel{\circ}{m}$ & $\bar{\infty}$ & $\begin{array}{l}0 \\
0 \\
0\end{array}$ & 웅 & $\begin{array}{l}\infty \\
\text { ò } \\
\text { m }\end{array}$ & ¿ \\
\hline $\begin{array}{l}\infty \\
\stackrel{\infty}{\alpha}\end{array}$ & 志 & $\begin{array}{c}m \\
\infty \\
0 \\
\stackrel{m}{-} \\
\stackrel{n}{-}\end{array}$ & $\frac{0}{0}$ & $\frac{n}{n}$ & $\begin{array}{l}\infty \\
0 \\
0 \\
0 \\
0 \\
-\end{array}$ & 足 & $\stackrel{\infty}{\stackrel{\infty}{\kappa}}$ & $\begin{array}{l}0 \\
\stackrel{0}{0} \\
\text { in }\end{array}$ & $\begin{array}{l}0 \\
\text { రิ } \\
\text { กิ }\end{array}$ & $\begin{array}{c}\frac{n}{=} \\
\bar{n} \\
m \\
m\end{array}$ & $\begin{array}{l}\infty \\
\infty \\
\infty \\
\infty \\
\infty \\
\infty\end{array}$ \\
\hline${ }^{\circ}$ & $\frac{n}{i n}$ & $\stackrel{\simeq}{\simeq}$ & $\stackrel{0}{i}$ & $\stackrel{\infty}{i}$ & 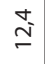 & İ & $\begin{array}{l}\infty \\
\infty\end{array}$ & $\stackrel{\circ}{-}$ & $\stackrel{n}{-}$ & $\begin{array}{l}\stackrel{n}{ } \\
\stackrel{\infty}{\sigma}\end{array}$ & 음 \\
\hline $\begin{array}{l}\hat{\alpha} \\
\text { a } \\
\end{array}$ & 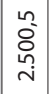 & 志 & $\frac{\hat{0}}{6}$ & 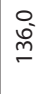 & $\begin{array}{l}\tilde{N} \\
\tilde{O} \\
0\end{array}$ & 웅 & $\stackrel{\mathcal{F}}{\stackrel{\mathcal{F}}{2}}$ & $\begin{array}{l}\text { ㅇ. } \\
\text { in }\end{array}$ & $\frac{n}{\pi}$ & $\begin{array}{l}\stackrel{o}{0} \\
\stackrel{h}{n} \\
\stackrel{n}{N}\end{array}$ & \begin{tabular}{l}
\multirow{N}{*}{} \\
$\infty$ \\
$\infty$ \\
$\dot{\sigma}$
\end{tabular} \\
\hline$\therefore$ & $\frac{n}{i n}$ & $\stackrel{g}{+}$ & $\stackrel{+}{m}$ & : & $\stackrel{\cong}{\check{a}}$ & $\stackrel{\infty}{0}^{\circ}$ & 永 & $\stackrel{\underline{n}}{\stackrel{m}{n}}$ & $\hat{i}$ & $\begin{array}{l}\stackrel{\sigma}{\alpha} \\
\stackrel{\infty}{+}\end{array}$ & 음 \\
\hline ڤ̊ & $\begin{array}{c}m \\
\tilde{n} \\
\stackrel{2}{\alpha} \\
-\end{array}$ & స్ & $\stackrel{\substack{0 \\
\infty}}{\stackrel{\infty}{\simeq}}$ & ㅇ. & $\hat{\tilde{f}}$ & $\tilde{\mathcal{Z}}$ & 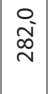 & $\begin{array}{l}a \\
\text { in } \\
\text { in }\end{array}$ & oq & $\begin{array}{c}\hat{N} \\
\substack{\infty \\
-}\end{array}$ & $\begin{array}{l}a \\
\hat{0} \\
0 \\
0 \\
\dot{m}\end{array}$ \\
\hline$\therefore$ & $\begin{array}{l}\dot{0} \\
\text { cे }\end{array}$ & $\stackrel{\infty}{+}$ & $\stackrel{q}{-}$ & $\stackrel{t}{m}$ & $\overline{ \pm}$ & $\pi$ & $\hat{m}$ & 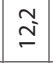 & $\stackrel{\sim}{m}$ & $\begin{array}{l}0 \\
\stackrel{g}{\sigma}\end{array}$ & 음 \\
\hline$\stackrel{\text { ñ }}{\sigma}$ & 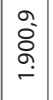 & $\begin{array}{l}\circ \\
\stackrel{0}{\circ}\end{array}$ & 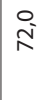 & 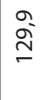 & 足- & i̊ & 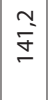 & $\begin{array}{l}\circ \\
\text { ò } \\
\text { yे }\end{array}$ & $\overline{\check{D}}$ & $\begin{array}{c}\bar{N} \\
\underset{\infty}{\alpha} \\
-\end{array}$ & 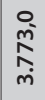 \\
\hline$\therefore$ & $\begin{array}{c}m \\
\omega_{m}^{n}\end{array}$ & $\stackrel{0}{m}$ & a & \pm & $\begin{array}{l}\stackrel{0}{m} \\
\stackrel{m}{n}\end{array}$ & $\hat{0}$ & $\stackrel{\sim}{m}$ & $\begin{array}{l}\infty \\
n^{\infty}\end{array}$ & $\bar{\sigma}$ & 莳 & 음 \\
\hline 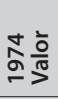 & $\begin{array}{l}0 \\
\infty \\
0 \\
0 \\
- \\
-\end{array}$ & 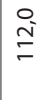 & స్ & $\begin{array}{l}\stackrel{0}{\tilde{q}} \\
\stackrel{\sim}{*}\end{array}$ & $\hat{\tilde{N}}$ & ō & बे & $\begin{array}{l}\stackrel{0}{1} \\
\infty \\
\infty\end{array}$ & $\stackrel{\sim}{\sim}$ & 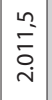 & $\begin{array}{l}n \\
0 \\
0 \\
\dot{m}\end{array}$ \\
\hline$\therefore$ & $\hat{\text { ⿵े }}$ & in & $\hat{o}$ & テ & $\begin{array}{l}\infty \\
0 \\
0\end{array}$ & $\stackrel{\infty}{=}$ & $\stackrel{\infty}{+}$ & $\stackrel{m}{\underset{I}{\sim}}$ & ָ̃ & $\begin{array}{c}m \\
\text { o }\end{array}$ & 음 \\
\hline $\begin{array}{l}m \\
\text { â음 }\end{array}$ & 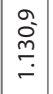 & $\stackrel{\circ}{\stackrel{y}{\Xi}}$ & $\bar{\sigma}$ & $\stackrel{m}{\stackrel{n}{\Sigma}}$ & $\begin{array}{l}0 \\
\grave{o} \\
m\end{array}$ & $\begin{array}{l}\text { ñ } \\
\text { in }\end{array}$ & 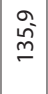 & $\begin{array}{l}0 \\
\hat{N} \\
\end{array}$ & $\therefore$ & $\begin{array}{c}m \\
\infty \\
\stackrel{\infty}{T} \\
\end{array}$ & 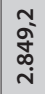 \\
\hline$\therefore$ & 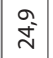 & $\stackrel{0}{m}$ & $\tilde{\sigma}$ & $\stackrel{\text { aे }}{ }$ & $\stackrel{g}{r}$ & $\stackrel{n}{N}$ & $\bar{m}$ & $\stackrel{\stackrel{n}{n}}{m}$ & $\stackrel{\simeq}{\simeq}$ & $\bar{n}$ & 음 \\
\hline $\begin{array}{l}\text { No흠 } \\
\text { 잉 }\end{array}$ & 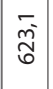 & ڤે & $\stackrel{\sigma}{m}$ & $\stackrel{n}{N}$ & స్ & $\begin{array}{l}\tilde{n} \\
\tilde{\tilde{n}}\end{array}$ & $\stackrel{2}{\Sigma}$ & $\begin{array}{l}0 \\
\infty \\
\infty\end{array}$ & ন্ & 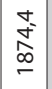 & 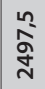 \\
\hline 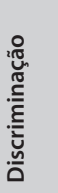 & 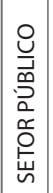 & 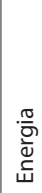 & $\begin{array}{l}\frac{\pi}{0} \\
\frac{\pi}{2} \\
\frac{0}{0} \\
\text { in }\end{array}$ & 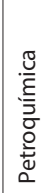 & 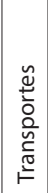 & 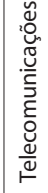 & 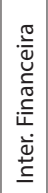 & 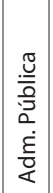 & 蒙 & 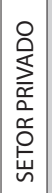 & సँّ \\
\hline
\end{tabular}


A questão do acesso às tecnologias também se colocava como outra fragilidade que se manifestava no II PND desde a sua elaboração, estabelecendo limites ao desenvolvimento setorial. Ela refletia a continuidade da dependência externa da economia brasileira ao capital internacional, identificada por duas dimensões:

Do lado da demanda de tecnologia, teríamos o comportamento do mercado consumidor de bens de consumo duráveis, em que a absorção de um padrão de consumo de economias desenvolvidas nos tornava também reféns da importação de uma tecnologia estranha e não adaptada às nossas características internas; por outro lado, do ponto de vista da oferta de tecnologia, a presença da empresa multinacional no país, tendo a demanda de know-how plenamente satisfeita por suas matrizes, induzia padrões de eficiência, diferenciação do produto, orientação do consumo interno e abertura ao exterior incompatíveis com a formação histórica de nossos centros de pesquisas, e forçando, assim, as empresas nacionais mais dinâmicas e competitivas a se manterem dependentes das importaçóes tecnológicas, como forma de defenderem os mesmos níveis de incorporação técnica determinados pelo ritmo da empresa multinacional (CAMPOS, 2009, p. 86) .
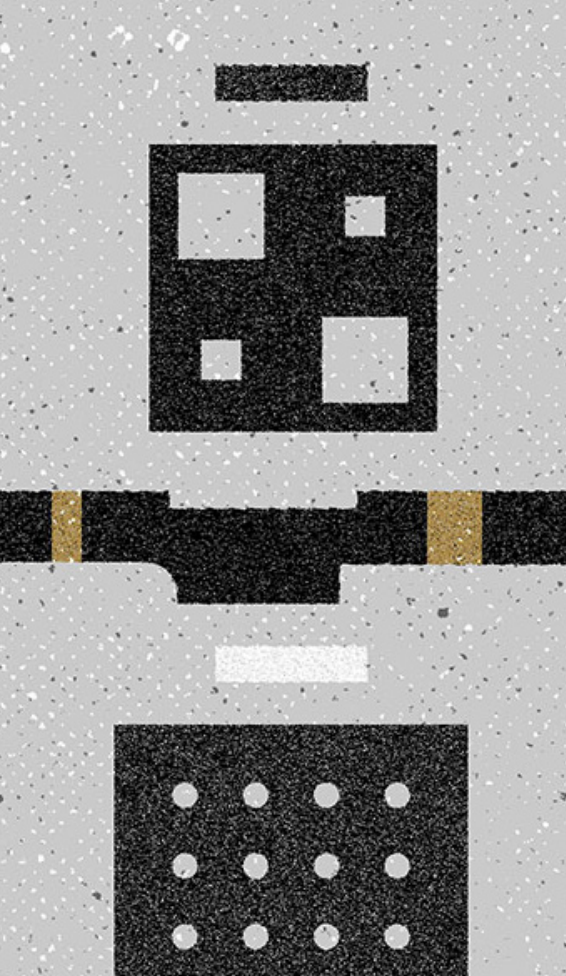
Especificamente, a realização dos empreendimentos do plano forçava o crescimento da transferência tecnológica e das importaçóes de bens de capital, em detrimento da produção doméstica. A principal explicação para isto estava na elevada complementariedade existente nesse setor, decorrente, “da estreiteza do parque produtor já instalado, bem como das dificuldades dessa natureza tecnológica para substituir muitas das importações” (SERRA, 1998, p. 113). Ademais, a atuação dos organismos internos do governo no setor, como o CDI e o INPI, ao invés de buscar alternativas para reforçar a capacidade de as empresas privadas nacionais participarem da realização dos grandes empreendimentos de vanguarda, criavam meios de impulsionar a entrada desses bens de capital, mantendo a indústria doméstica refém das importações.

Em suma, esses limites concernentes à centralização do Estado na execução de um plano de desenvolvimento fadado ao fracasso, como foi o II PND, criaram no decorrer do processo de execução do mesmo uma série de descontinuidades, as quais foram responsáveis pela longa estagnação da economia brasileira iniciada nessa fase. No final da década de 1970 e início dos anos 1980, a balança comercial brasileira voltou a ter um déficit, "acumulando um saldo negativo de US\$ 5,7 bilhôes, como resultado direto do segundo choque do petróleo" (RODRIGUES, 2017, p. 103). Nessa mesma fase as líquidas externas totalizaram 9,2 bilhões de dólares, os juros líquidos alcançaram o montante de 10,5 bilhões de dólares, (CRUZ, 1984, p. 24).

Nesse cenário corrente de crise fiscal e financeira do Estado, endividamento público externo, contração da liquidez internacional e dos investimentos externos, as preocupaçóes do Estado se deslocaram para a criação de políticas de estabilização orientadas a controlar a dívida externa, reduzir os desequilíbrios nos balanços de pagamentos e a inflação (BONELLI \& MALAN, 1976). Diante disso, o Estado brasileiro deixou de intervir diretamente no processo de implantação da indústria pesada através do planejamento econômico, se submetendo inteiramente à autonomia do capital internacional, cujo objetivo principal nesta fase, passou a ser o de manter a subordinar a economia brasileira às vicissitudes da internacionalização financeira.

\section{CONCLUSÃO}

O II PND se colocou como mais uma estratégia de desenvolvimento capitalista, que vislumbrou a possibilidade de dar continuidade ao processo de substituição de importaçôes, num momento em que o padrão mundial de acumulação estava se reestruturando, em resposta à crise estrutural do 
capital que se impunha. Nesse sentido, a sua realização dependia da capacidade do Estado em criar, por meio do planejamento econômico, as condiçôes que atendessem as novas exigências impostas pelas empresas multinacionais, para continuarem a investir aqui naquela fase.

Para tanto, o Estado deu às empresas estatais um papel central nesse processo, lhes conferindo as funçóes de demandantes de bens de capital, tomadoras de recursos externos, e, sobretudo, promovendo a associação destas com empresas privadas nacionais e estrangeiras, formando as joint ventures. Essa forma de associação, ao estimular a entrada de empresas multinacionais para atuarem na exploração dos recursos naturais, insumos básicos e matérias-primas, para depois serem comercializados, promoveu a realização uma parte das metas do plano, especialmente daquelas localizadas no setor de insumos básicos, que recebeu a maior parte dos investimentos externos. Por outro lado, essa escolha do Estado possibilitou à empresa multinacional a continuar se apropriando de parte do excedente que era produzido pelas estatais e, posteriormente, transferido para essas empresas a preços subsidiados, bem como a captar recursos externos e importaçốes etc; a serem utilizadas na execução do plano.

Desse modo, à medida que as metas setoriais do II PND eram concluídas, mais avançava o processo de internacionalização da economia brasileira, de modo a definir, na fase posterior, um tipo de acumulação assentado essencialmente na internacionalização financeira. O fracasso do II PND, bem como as vicissitudes criadas ao longo da sua execução, nos revela os limites existentes num plano de desenvolvimento que se prestou a concluir a industrialização pesada numa estrutura econômica desequilibrada e dependente, como a brasileira.

\footnotetext{
Notas

1 O referido autor indica como essa "ilusão" foi derrubada, de fato: "O capital alcançou este resultado mediante, por um lado, a força intrínseca que recuperou graças à longa fase de acumulação dos "trinta anos gloriosos" e, por outro, as tecnologias que as firmas - em primeiro lugar os grandes grupos perseguidos pela concorrência dos grupos japoneses - souberam utilizar para seus próprios fins, principalmente com o intuito de modificar suas relações com os assalariados e as organizações sindicais. Mas o capital industrial e financeiro beneficiou-se também de um apoio fundamental por parte dos principais Estadoscapitalistas, sob a forma das políticas de liberalização, desregulamentação e privatização que estes adotaram, um após o outro, desde a chegada ao poder dos governos de Thatcher e de Reagan. Desta forma, o capital voltou a ter liberdade para se desenvolver e, principalmente, para se movimentar em âmbito internacional de um país ou continente para outro - liberdade que não desfrutava desde 1914" (Chesnais, 1995, p.02).

2 É importante ressaltar que essa foi uma crise temporária dos primeiros anos, pós-ruptura com o padrão estabelecido em Bretton Woods.
} 
${ }^{3} \mathrm{O}$ excesso de liquidez internacional do pós Segunda Guerra Mundial, expresso pelo poder do dólar enquanto moeda internacional, levou à constituição do Euromercado. O Euromercado consistia no mercado de eurodólares, cuja maior liberdade nos empréstimos resultaram em empréstimos com taxas de juros flutuantes. E "quem se beneficiará particularmente dessa conjuntura de largueza financeira, abrindo-lhe perspectivas e oportunidades imensas, serão naturalmente, em primeiro lugar, os grandes trustes e monopólios norte-americanos, e logo em sequência, das demais potências capitalistas, em especial a Alemanha e o Japão [...].(PRADO JR., 2006, p. 347-348).

${ }^{4}$ Disponível em: http://www.fau.usp.br/docentes/depprojeto/c_deak/CD/5bd/2br/3plans/1974II-PND/ pdf/II-PND.pdf. Acesso em: 20 ago. 2020.

${ }^{5}$ O período conhecido como milagre econômico representou uma fase em que as exportações brasileiras cresceram a uma taxa média anual extremamente elevada quando comparada aos demais países latinoamericanos. Entretanto, tal fato não se "deveu exclusivamente a uma condução eficiente de política econômica, mas exclusivamente à conjunção de uma fase de recuperação cíclica da economia brasileira com uma conjuntura internacional excepcionalmente favorável" (BONELLI \& MALAN, 1976, p. 355).

${ }^{6}$ Disponível em: http://www.bcb.gov.br/pre/normativos/circ/1974/pdf/circ_0230_v10_l.pdf.

7 "A Lei 4.131 procurou repor o controle ao capital internacional que a Instrução 113 havia suprimido, tornando-se um dos elementos mais relevantes da argumentação dos setores conservadores contra o governo. Por outro lado, ela também simbolizou o questionamento da internacionalização brasileira, constituindo-se como uma das razões pela qual o Golpe de 64 não foi mero resultado da conspiração dos quartéis, mas, acima de tudo, dos interesses reais constituídos em parte pelo próprio capital internacional"(CAMPOS, 2003, p.144).

${ }^{8}$ Destes instrumentos financeiros criados na década de 1970, a Resolução n 432 foi responsável por impulsionar a estatização (socialização) da dívida externa, no intuito de proteger os devedores em moeda estrangeira de dos possíveis aumentos de juros e das desvalorizações cambiais. Em outras palavras, a partir dessa Resolução "qualquer devedor ao exterior poderia, a qualquer tempo, transferir ao Banco Central, em caráter temporário ou definitivo, o remanescente de sua dívida nas condições contratadas, desde que nele depositasse os cruzeiros correspondentes ao principal da obrigação na data. Foi o sinal para a estatização crescente da dívida privada, a um custo em dólares para o Banco Central equivalente ao spread arbitrado pelo credor e aceito pelo devedor originais - não raro, matriz externa e subsidiária interna de um mesmo banco, ou vice-versa". (TAVARES \& ASSIS, 1985, p. 70).

9 "Através, primordialmente, de esforço conjugado do MIC, MME e BNDE, será dado amplo e imediato apoio a empreendimentos liderados pelo setor privado, que deverá ser o principal responsável pela área de insumos básicos. Sem embargo, não se permitirá a sistemática procrastinação, por longos anos, do uso de reservas conhecidas de certos minérios de alto interesse nacional, pela indefinição dos grupos interessados, procurando se, para cada projeto, a solução gerencial adequada, se for o caso através de associação entre empresas privadas e governamentais" (II PND, 1974, p. 39).

${ }^{10}$ Segundo o discurso oficial da época proferido pelo Presidente da República e enaltecido nas obras escritas por alguns defensores do II PND, tais como: Antônio Barros de Castro, Mário Henrique Simonsen, João Paulo dos Reis Veloso, Roberto Campos e Delfim Netto, a política de incentivos governamentais praticada pelo Estado nessas empresas em curto prazo alteraria, num segundo momento, o estilo de desenvolvimento da economia brasileira, de forma a dotá-la de uma estrutura industrial moderna e poderosa.

${ }^{11}$ Posteriormente essa subsidiária da Petrobrás mudou o nome para Interbrás e passou a assumir o papel de uma trading Company Internacional no estilo japonês.

${ }^{12}$ De acordo com Tamer (1980), ao longo da década de 1970 grandes grupos estrangeiros em regime de contrato de risco controlavam a exploração do petróleo, tais como: Agip, Allied Chemical Corporation, BP, Cities Service Company, Ensearch Exploration Inc., Exxon, Hispanoil, Hudson's Bay Oil and Gas Company Ltd., Occidental Petroleum Corporation, Ocean Drilling \& Exploration Company, Pennzoil, Shell, Société National Elfaquitaine, Standard Oil e Union.

${ }^{13}$ O Brasil teve de gastar U\$ 3,5 bilhões - em dólares - com importações de petróleo em 1975. Isto significa que tiveram de ser pagos diariamente U\$\$ 10 milhões em divisas estrangeiras pelo petróleo importado - o total foi de 30,5 por cento de todas as moedas fortes que o Brasil ganhou em 1975. Em 1976, o gasto deverá chegar a U\$\$ 4 bilhões, que poderão constituir tanto como 40 por cento da importação total do valor" (SMITH, 1976, p. 201).

${ }^{14}$ Disponível em: http://www2.aneel.gov.br/arquivos/PDF/dlg1973023_IATIPU.pdf. 


\begin{abstract}
${ }^{15}$ Vejamos alguma das empresas integrantes destes consórcios: Unicon: Cetenco Engenharia Ltda.; CBPO - Cia. Brasileira de Pavimentos e Obras; Camargo Corrêa; Andrade Gutierrez; e Mendes Júnior. Conempa: A Barrail Hermanos; Cia. General de Construcciones; ECCA S.A.; e Jimenez Gaona \& Lima. Itamon: A. Araújo S.A. - Engenharia e Montagem; Empresa Brasileira de Engenharia S.A. - EBE; Montreal Engenharia S.A.; Sade - Sul Americana de Engenharia S.A.; Sertep - Engenharia e Montagem S.A.; Techint - Companhia Técnica Internacional; Tenenge - Técnica Nacional de Engenharia S.A.; e Ultratec Engenharia S.A.AG Brown Boveri \& Cie; Alstom Atlantique; Bardella S.A. Indústrias Mecânicas; BSI - Indústrias Mecânicas S.A.; Brown Boveri \& Cie. AG; Indústria Elétrica Brown Boveri S.A.; J.M. Voith GmbH; Mecânica Pesada S.A.; Neyrpic; Siemens Aktiengesells-chaft; Siemens S.A.; e Voith S.A. Máquinas e Equipamentos. Essas informações estão disponíveis em: https://www.itaipu.gov.br/sala-de-imprensa/perguntas-frequentes. Acessado em 23/09/2019.

${ }^{16}$ No Tratado de Itaipu ficou determinado, em comum acordo entre as partes, que as garantias aos empréstimos internacionais contraídos para a execução das obras de Itaipu fossem dadas pela Eletrobrás, de forma que as consequências disso fossem assumidas pelo Estado brasileiro.

${ }^{17}$ Essa transferência era explicada pela irredutibilidade do Grupo Pignatari na negociação com vários grupos estrangeiros, como o Kaiser Aluminum, que se interessou em participar da iniciativa, mas foi vetado. Por conta desse insucesso, em 1974, o projeto foi estatizado, de modo que o Banco Nacional de Desenvolvimento Econômico e Social (BNDES) assumiu a jazida de seu prosseguimento ao programa de exploração de instalação de sua unidade metalúrgica (BNDES, 1986).

${ }^{18}$ De acordo com Oliveira (2004), o resultado dessa aliança societária na indústria química brasileira foi a formação da CPC - Cia. Petroquímica de Camaçari, uma joint venture que integra o Polo Industrial de Camaçari, localizado no município de Camaçari se estendendo até Dias d'Ávila, no estado da Bahia, no Brasil.

${ }^{19} \mathrm{Em}$ 1971, o Estado criou a Central de Medicamentos (CEME) para preencher o que era considerado como uma lacuna na assistência médica pública, porém, a base produtiva dessa estatal nem se comparava com as poderosas multinacionais que dominavam a indústria farmacêutica. "A distancia entre a CEME e as principais multinacionais era ainda maior em termos de sofisticação tecnológica. Os remédios produzidos nos seus laboratórios não incluíam os mais novos e avançados antibióticos, esteroides ou hormônios. Dos milhares de produtos farmacêuticos existentes no comércio, o momento terapêutico da DEME incluía apenas 80"(EVANS, 1980, p. 221)

${ }^{20}$ De acordo com Campos (2009, p. 92): "Em linhas gerais, tal autonomia nacional, que também passava por uma Campanha contra a Estatização, era enunciada pela ABDIB nos seguintes termos: 1) - proibição absoluta de incentivos aos investimentos contratados no exterior; 2) - veto à criação de departamento de engenharia dentro de empresas estatais; 3) - criação de reservas de mercado para a tecnologia nacional; 4) - garantia de mercado à oferta nacional de produtos do setor".

${ }^{21}$ Para maiores detalhes sobre o caso da EMBRAER, ver Cardoso (2018).

${ }^{22}$ Os dados desses parágrafos, bem como a sua interpretação estão baseados em Cruz (1984, p. 95 - 97).
\end{abstract}

\section{Referências}

ABRANCHES, S.H.H. Empresa estatal e capitalismo: uma análise comparada. In: MARTINS, C. E (Org.). Estado e Capitalismo no Brasil. São Paulo, Hucitec, 1977.

\begin{abstract}
ANDERSEN, S. Geopolítica e energia na Bacia do Prata: O caso emblemático de Itaipu. I Simpósio Nacional de Geografia Política, Território e Poder, 2009. Disponível em https://bit.ly/3loXLoJ. Acesso em: 22 nov. 2019.
\end{abstract}

BAER, M. A internacionalização financeira no Brasil. Petrópolis, Vozes, 1986.

BARANSON, J. Tecnologia e as empresas multinacionais: estratégias da empresa numa economia mundial em transformação. Rio de Janeiro: Zahar, 1980.

BARAT, J. A evolução dos transportes no Brasil. Rio de Janeiro: IBGE/IPEA, 1978.

BNDES. Estudo do Mercado Brasileiro de Cobre. Rio de Janeiro, 1986, 70 p.

BONELLI, R. e MALAN, P.S. Os Limites do impossível: notas sobre o balanço de pagamentos e indústria nos anos 70.Pesquisa e Planejamento Econômico, v.6, n. 2, Rio de Janeiro, 1976.

BRASIL. Presidência da República. II Plano Nacional de Desenvolvimento (II PND), Brasília, Setembro de 1974. 
CAMPOS, F. A. Estratégias de

Desenvolvimento Nacional: o papel do capital estrangeiro entre o segundo Governo Vargas e o Governo Castelo Branco (1951-1966). Campinas: 2003. Dissertação (Mestrado) - Instituto de Economia - Universidade Estadual de Campinas.

CAMPOS, F. A. de. A arte da conquista: o capital internacional no desenvolvimento capitalista brasileiro (1951-1992). Campinas: 2009. Tese (Doutorado) - Instituto de Economia - Universidade Estadual de Campinas.

\section{CAMPOS, F.A; RODRIGUES, F.H.L.}

Transnacionalização do Capital e os Limites do Desenvolvimentismo: um diálogo com Celso Furtado sobre a Experiência Brasileira (1956-1982). História Econômica \& História das Empresas, v. $17 \mathrm{n}$.

2, p. 377-414, 2014.

CAMPOS, F. A. Imperialismo e colapso da formação econômica brasileira. In: MAZIN, A. D.; NOVAES, H.; PIERES, J. H.; LOPES. J. A. (Orgs.). Questão agrária, cooperação e agroecologia. São Paulo: Outras Expressões, v.2, 2016.

CANTANHEDE, P. "As Empresas multinacionais e a siderurgia" Revista de Administração Pública, v.10, n.1, jan-mar, 1976.

CAUBET, C. G. As grandes manobras de Itaipu: energia, diplomacia e direito na Bacia do Prata. São Paulo: Revista Acadêmica, 1989.

CARDOSO, A.M. A Embraer e a Questão Nacional. Campinas: 2018. Tese (Doutorado) - Instituto de Economia, Universidade Estadual de Campinas.

CAVALCANTI, C. B. Transferência de recursos ao exterior e substituição de divida externa por dívida interna. Rio de Janeiro, BNDES, 1988

CHESNAIS, F. A globalização e o curso do capitalismo de fim-de-século. Economia e Sociedade, Campinas, n. 5, p. 1-30, dez.1995.
CRUZ, P. D. Dívida externa e política econômica: a experiência brasileira nos anos setenta. São Paulo: Brasiliense, 1984.

EICHEGRENN. B. A globalização do capital: uma história do sistema monetário internacional. São Paulo: Editora 34, 2000.

EVANS, P. A tríplice aliança: as multinacionais, as estatais e o capital nacional no desenvolvimento dependente brasileiro. Rio de Janeiro: Zahar, 1980.

FILHO, A.G. Presença e ausência do Estado na trajetória da indústria da construção naval brasileira - 1959-1989. In: Revista Nova Economia, v.24. Belo Horizonte Maio/ Agosto, 2014.

FISHLOW, A. A economia política do ajustamento brasileiro aos choques do petróleo: uma nota sobre o período 1974/1984. Pesquisa e Planejamento Econômico, v. 16, n.3, Rio de Janeiro, 1986.

FURTADO, C. Brasil: a construção interrompida. 2. ed. Rio de Janeiro: Paz e Terra, 1992.

GEISEL, E. . Discursos: vol. 1 - 1974. Brasília: Imprensa Nacional, 1974.

LESSA, C. A Estratégia de desenvolvimento, 1974/76: sonho e fracasso. 2.ed. Campinas: Unicamp - IE, 1998.

LESSA, C. Visão crítica do II PND. Tibiriçá, ano II, n.6, jan/mar, 1977.

MACARINI, J.P. Governo Geisel: transição político-econômica? um ensaio de revisão. In: Revista de Economia Contemporânea, v. 15, n. 1, p. 30-61, Rio de Janeiro, 2011.

MANDEL, E. A Crise do Capital:os fatos e sua interpretação marxista. São Paulo: Ensaio, 1990.

MANTEGA, G. Acumulação de capital, crise e capital estrangeiro. In: MANTEGA, G; MORAES, M (Orgs.). Acumulação monopolista e crises no Brasil. Rio de Janeiro: Paz e Terra, 1979.

MARTINS, L. Estado capitalista e burocracia no Brasil pós-64. Rio de Janeiro: Paz e Terra, 1985. 
MESZAROS, I. A crise estrutural do capital. São Paulo: Boitempo, 2009.

MIRANDA, M.B. A Empresa Binacional Itaipu. In: Revista Virtual Direito Brasil, v.2, $\mathrm{n}^{\circ} 2-2008$.

\section{MORAES, R. O Canto do cisne do} desenvolvimentismo brasileiro - uma análise das relações do empresariado industrial com o Estado do II PND à crise dos anos 1980. Campinas: 2018. Tese (Doutorado) - Instituto de Economia, Universidade Estadual de Campinas.

NONNEMBERG. M.J.B. "Determinantes dos investimentos externos e impactos das empresas multinacionais no Brasil - As décadas de 1970 e 1990". Texto para Discussão, n. 969, IPEA - RJ, 2003.

OLIVEIRA, A. O Polo Petroquímico de Camaçari (Bahia, Brasil): industrialização, crescimento econômico e desenvolvimento regional. Salvador: 2004. Tese (Doutorado)

- Programa de Pós Graduação em Geografia - UNIFACS.

REICHSTUL, H. P; COUTINHO, L.G. Investimento estatal 1974-1980: ciclo e crise. In: COUTINHO, R; BELLUZZO, L.G.M. Desenvolvimento capitalista no Brasil: Ensaios sobre a crise. Vol. 2. São Paulo: Brasiliense, 1983.

RODRIGUES, C.H.L. Imperialismo e Empresa Estatal no Capitalismo Dependente Brasileiro (1956-1998. Campinas: 2017. Dissertação (Mestrado) -Instituto de Economia UNICAMP.

SCHUTTE, G. R. Elo perdido: O estado globalização e a indústria petroquímica no Brasil , São Paulo, Annablume, 2003.

SERRA, J. Ciclos e mudanças estruturais na economia brasileira do pós-guerra. In:
(Orgs.) BELLUZZO, L. G. M. e COUTINHO, R. Desenvolvimento capitalista no Brasil: ensaios sobre a crise. 4.ed. Campinas: Unicamp-IE, 1998.

SILVA, R. A. A . Brasil-Paraguai: marcos da política pragmática na reaproximação bilateral, 1954-1973: um estudo de caso sobre o papel de Stroessner e a importância de Itaipu. 141 f. 2006. Dissertação (Mestrado em Relações Internacionais)- Universidade de Brasília, Brasília, 2006.

SMITH, P. S. Petróleo e Política no Brasil Moderno. Rio de Janeiro: Antenova, 1976.

TAMER, A. Petróleo, o preço da dependência. Rio de Janeiro: Nova Fronteira, 1980.

TAVARES, M.C; ASSIS, J. C. O grande salto para o caos: a economia política e a política econômica do regime autoritário. $2^{\mathrm{a}}$ edição. Rio de Janeiro: Jorge Zahar Editor, 1985.

TORRES FILHO, E. T. "O Novo ciclo do investimento direto japonês e o Brasil". Texto para Discussão, n.237, da UFRJ/IEI, jun, 1990.

TREBAT, T. Uma avaliação do desempenho econômico das grandes empresas estatais no Brasil: 1965/75. In: Pesq. Plan. Econ. Rio de Janeiro, 10(3), p.813-850, dez. 1980.

VELOSO, J. P. d. R. Brasil, a solução positiva. São Paulo: Abril-Tec Editora, 1978. 8

WROBEL P. S. A questão nuclear nas relações Brasil-EUA. Dissertação de mestrado. Rio de Janeiro: IUPERJ, 1986.

ZONINSEIN, J. e TEIXEIRA, A. "Joint ventures (JV) na industrialização brasileira: notas para estudo das formas do capital". Texto para Discussão, n.29, IEI-UFRJ, 1983.

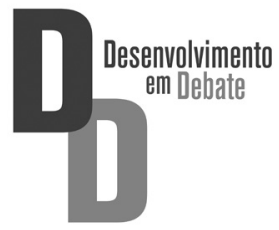

